\title{
Los estadios morales de la evolución social
}

\author{
Juan Carlos Alútiz \\ Universidad Pública de Navarra. Departamento de Sociología \\ Campus Arrosadía, s/n. 31006 Pamplona \\ jcalutiz@unavarra.es
}

\section{Resumen}

El objetivo de este trabajo es el de proponer un concepto de evolución social genuinamente sociológico, en el que se venga a dar cuenta de la racionalidad sociocultural como un proceso de coimplicación entre los estadios cognitivos de la psique humana descubiertos por la psicología del desarrollo, y las diferentes configuraciones discursivo-cognitivas de las «imágenes del mundo» históricas en torno a los tres mundos de la experiencia (el objetivo, el social y el subjetivo). Esta coimplicación evolutiva, ya mencionada por Habermas, se nos mostraría de manera ejemplar en la posibilidad de señalar tres estadios morales para la evolución social, que este artículo trata de presentar, precisamente, de manera desglosada.

Palabras clave: evolución, moralidad, imágenes del mundo, estadios cognitivos, racionalidad sociohistórica.

\section{Abstract. The moral stages of the social evolution}

The objective of this work is to propose a sociological concept of social evolution which explain the sociocultural rationality like an overlapping process between the cognitive stages of the human awareness discovered by the psychology of the development, and the different discursive-cognitive configurations of the images of the historical world around the three worlds of the experience (the objective world, the social world, and the subjective world). This overlapping evolutionist, already mentioned by Habermas, it would exemplary be shown in the possibility of pointing out three moral stages for the social evolution, that this article tries to present, in fact, in a detailed way.

Key words: evolution, morality, images of the world, cognitive stages, sociocultural rationality.

\section{Sumario}

Introducción El estadio moral posconvencional de las sociedades históricas posaxiales

Sobre la posibilidad de definir estadios morales de la evolución social Conclusiones

El estadio moral preconvencional Bibliografía de las sociedades históricas preaxiales

El estadio moral convencional de las sociedades históricas axiales 


\section{Introducción}

Después de las críticas vertidas sobre el concepto de evolución social, especialmente contra las teorías darwinistas y positivistas de antropólogos y sociólogos del siglo XIX, parece que utilizar dicho término como título de un texto es sinónimo de desprestigio o, cuando menos, de desconfianza hacia las ambiciones teóricas totalizantes que, con casi seguridad, se van a encontrar indicadas en el mismo.

La principal crítica a los diferentes conceptos de evolución social gestados por la sociología hasta fechas muy recientes procede, mayoritariamente, de la carga "determinista» que se suele inferir como horizonte realizativo del desarrollo social (especialmente presente en la escuela antropológica del relativismo cultural), de tal modo que al final siempre se tiende a equiparar la visión de una teleología histórica con una doctrina social. Tal sería el caso, por ejemplo, tanto del positivismo darwinista que preconizaba la Ilustración, como del marxismo ortodoxo que auguraba la parusia de una hermandad comunista. Por el contrario, en el marco posmoderno actual sobre el que forzosamente tenemos que levantar nuestros modelos teóricos, no se puede conceder preeminencia a ninguna visión histórico-valorativa de la realidad social sobre el resto, con lo que un concepto determinista de la evolución aparecerá desprestigiado, por necesidad, antes incluso de tomar forma ${ }^{1}$. La pregunta, entonces, que nos tendremos que formular es si es posible construir un concepto de evolución que no se encuentre prisionero de un horizonte utópico, sin que por ello se desvirtúe su propia idiosincrasia sociológica que nos permita caracterizar y clasificar temporalmente a las sociedades históricas.

Entre todos los intentos de respuesta a esta pregunta, quizás el que ha alcanzado una mayor fertilidad y credibilidad es el paradigma comunicativo, tanto en su versión de la teoría de la acción comunicativa de Jürgen Habermas como en su versión de la teoría de los sistemas autopoiéticos de Niklas Luhmann. La propuesta de Habermas, aunque apela a un supuesto carácter deontológico en su construcción para deshacerse de acusaciones doctrinarias, al partir de la tradición sociológica de las teorías de la acción, todavía va a necesitar apoyarse sobre la categoría de "sentido", y, en consecuencia, mantiene un cierto horizonte utópico bajo la forma de una autorrealizazión racional-discursiva del ser humano ${ }^{2}$. Por el contrario, la teoría de sistemas de Luhmann, al construirse a espaldas del actor social, puede ser lo suficientemente radical para sal-

1. Bauman, siguiendo en cierto modo el camino frankfurtiano de la "dialéctiva de la Ilustración», será especialmente crítico contra estos intentos residuales de la modernidad por universalizarse como destino incuestionado sobre valores tales como el racionalismo o el progreso. Ver Bauman, Z., "Para una teoría sociológica postmoderna», Acta Sociológica, no 35, México, 2002, p. 165 s.; «Existe una sociología posmoderna?», Acta Sociológica, no 35, p. 191 s.

2. Como veremos, todo intento por establecer una clasificación moral de las sociedades no puede escapar a la necesidad de fijarse un horizonte moral o utópico para sí mismas, aunque, como en el caso de Habermas, se proponga definir a partir de los principios deontológicos de la ética del discurso. 
vaguardar el concepto de evolución sin comprometerlo con ningún destino histórico, pudiendo tan sólo anticipar que, previsiblemente, los sistemas sociales se orientarán en su conjunto hacia una mayor complejidad autoorganizativa.

No obstante, la imbricación evolutiva entre el hombre y la sociedad, a nuestro entender, trascendería el umbral explicativo luhmanniano de un mero «acoplamiento estructural», para emerger, más bien, como medida de un correlativo potencial de desarrollo, que, desde un concepto de evolución anclado en la tradición de la teoría de la acción (Weber, Habermas), tendría cabida en el concepto de «racionalidad». La coevolución entre hombre y sociedad en términos de racionalidad, se pondría de manifiesto, además, tal y como señalara Habermas, en la relación existente entre las etapas de desarrollo cognitivomorales descubiertas por la psicología evolutiva (Piaget, Köhlberg) y los tipos históricos de "racionalidad de las imágenes del mundo" (Jaspers, Weber). La posibilidad misma de poder realizar una equiparación entre unas y otras nos estaría indicando la conveniencia de considerar la coimplicación de la evolución social y la evolución cognitiva humana como partes de un mismo proceso evolutivo que se condiciona mutuamente, y que resulta especialmente visible en una reconstrucción histórica de la moralidad social ${ }^{3}$.

\section{Sobre la posibilidad de definir estadios morales de la evolución social}

Si pretendemos mantenernos fieles a un concepto de evolución social que dé cuenta de la coparticipación del desarrollo humano y del desarrollo social, el problema de la moral, como puente que posibilita la conexión entre los sistemas sociales y los sistemas de conciencia, se erige, por necesidad, como el objeto central de nuestras indagaciones. En este sentido, dos son las cuestiones que, en principio, deberíamos responder: en primer lugar, si es posible hablar de estadios evolutivos en el desarrollo psicológico de la conciencia moral, y, en segundo lugar, si se pueden equiparar para cada uno de ellos diferentes moralidades sociales correspondientes a estadios evolutivos sociales.

Para responder a la primera pregunta, no podemos sino saltarnos el parcelamiento disciplinario de las ciencias sociales para acudir a las teorías psicológicas que Piaget y Köhlberg elaboraron en sus respectivos trabajos. En estimación de estos autores, en el proceso de aprendizaje de los seres humanos hasta su vida adulta se podrían indicar ciertos umbrales cognitivos que vienen a recoger diferentes niveles de competencia para entender y resolver problemas empírico-analíticos o práctico-morales. Como se sabe, Köhlberg, siguiendo los trabajos precedentes de Piaget ${ }^{4}$, desglosa en tres etapas fundamentales los

3. Para Habermas, la evolución social se entiende como un desarrollo convergente entre los desafíos adaptativos planteados a los sistemas sociales y los procesos de aprendizaje inherentes a las nuevas demandas de racionalidad. Ver HABERMAS, J., La reconstrucción del materialismo histórico, Taurus, Madrid, 1992, p. 123 ss.

4. Ver la excelente investigación de PIAGET (1932) sobre El criterio moral del niño (Fontanella, Barcelona, 1977). En función de una metodología cualitativa de investigación sobre las 
progresos sobre las capacidades reflexivas en materia moral ${ }^{5}$. La primera etapa, llamada "preconvencional», pondría el énfasis sobre una motivación egoísta que sólo responde a las normas que tienen el respaldo de una sanción social, y cuya disponibilidad para la cooperación social se ciñe a una correspondencia de contraprestaciones mutuas. La segunda etapa, también llamada "convencional», internalizaría en el individuo, y concretamente en su sentido de la identidad personal, los valores cultural-normativos de una comunidad de vida que se encuentra más allá de los miembros que la componen, es decir, en afinidad con Durkheim, como una realidad propia de rango superior al individuo que éste «debe» respetar y preservar como algo sagrado. La cooperación social, que en este caso también se podría denominar «solidaridad social», vendría motivada por un bien común —identidad colectiva- por el que todos los individuos se sienten implicados y movilizados. La última etapa, denominada «pos-convencional», crearía una distancia entre las capacidades reflexivas abstractas del individuo y sus creencias particulares acordes a su adscripción comunitaria. En este contexto - la convivencia entre individuos procedentes de distintas comunidades de creencia-, el sujeto social necesita de nuevos conceptos universales de conducta, tales como la justicia, para ordenar sus nociones morales. La motivación principal para la cooperación social pasa a residir entonces en principios abstractos capaces de suscitar la adhesión «racional» de todos los implicados, tomando como referentes principales los derechos cívicos garantizados por los estados de derecho democráticos ${ }^{6}$.

reglas del juego de las canicas, Piaget consigue descomponer en tres etapas la evolución de la conciencia normativa en los niños en dependencia de su edad biológica.

5. Köhlberg, L., Psicología del desarrollo moral, Desclée de Brouwer, D.L., Bilbao, 1992. Köhlberg desglosa las tres etapas señaladas por Piaget en seis para poder hacerlas operativas según una metodología cuantitativa basada en cuestionarios. No obstante, los saltos "cualitativos» siguen presentándose en el agrupamiento de cada dos etapas. Las principales objeciones a esta teoría se dirigen hacia el conjunto de hipótesis sobre las que se sostiene su modelo evolutivo. En primer lugar, la proposición de etapas es irreversible y secuencial, con lo que no se admiten ni retrocesos ni saltos; en segundo lugar, las etapas constituyen una jerarquía de estructuras cognitivas, que dan cuenta de la trayectoria progresiva de la racionalidad reflexiva, y, por último, al igual que los paradigmas de Kuhn, cada etapa constituye una unidad estructurada de cognición independiente, con lo que no cabe la comparación (ni el diálogo) entre las diferentes etapas.

6. En estimación de autores como Selman o Puka, sería cuestionable eximir a Köhlberg de tener pretensiones fundamentadoras en materia de filosofía moral al realizar su clasificación de etapas psicomorales, pues el tercer estadio, como punto de llegada del desarrollo congitivo-moral, aparecería influenciado por una conceptualización política liberal al estilo de Rawls. Una de las principales reticencias de Habermas para aceptar esta etapa procede, precisamente, de esta influencia. Por ejemplo, para Rawls los derechos universales de los individuos como sujetos morales se refieren, en última instancia, a una ética de bienes de derechos subjetivos (libertades irrenunciables para la autorrealización del individuo), mientras que para Habermas, con una mayor influencia kantiana, los derechos no son subjetivos sino producto de la intersubjetividad comunicativa y los presupuestos procedimentales de la ética del discurso (el reconocimiento de cualquier otro como un interlocutor válido con el que se puede llegar al entendimiento en virtud de su «autonomía racional»). 
Una vez le hayamos concedido una cierta credibilidad a este primer presupuesto de los estadios cognitivo-morales, el segundo punto a demostrar, como es la posibilidad de equiparar los estadios cognitivos del desarrollo psicológico con los estadios evolutivos de las sociedades, resulta, desde luego, todavía más complejo. El autor que con mayor solvencia habría tomado la iniciativa de implicarse en este desafío, a pesar de todas las críticas inherentes a un planteamiento universalista evolutivo, no es otro que Jünger Habermas. Su estrategia conceptual pasa por clasificar las sociedades históricas desde un criterio de racionalidad sociocultural, importado de Weber bajo la categoría de «imágenes del mundo», para confrontarlo con las competencias cognitivoracionales características de cada uno de los estadios psicológicos, que, sumados a una reelaboración de la diferenciación de mundos cognitivos tomada de Popper $^{7}$, le permite confirmar la existencia de estadios evolutivos en la racionalidad sociohistórica.

No obstante, su explicación, basada sobretodo en datos obtenidos de la disciplina antropológica, no es tan satisfactoria como cabría esperar, pues tan sólo da cuenta de un estadio inicial primitivo y su estadio final contemporáneo, con el objetivo prioritario de demostrar un desarrollo efectivo de la racionalidad social cuestionado desde el relativismo cultural. Por ello, para realizar una exposición ordenada de cada uno de estos estadios de la evolución social, nos vemos forzados a recurrir a la primera formulación que realizara $\mathrm{K}$. Jaspers de las imágenes del mundo y su posterior redefinición desglosada por S.N. Eisenstadt.

El concepto de «imagen del mundo» de K. Jaspers habría que entenderlo como una resultante entre el "conocimiento-comunicación" del patrimonio cultural de cada sociedad, y el "conocimiento-experiencia» de cada individuo $^{8}$. La imagen del mundo es todo aquello por lo cual nos representamos la realidad externa como un espacio de experiencia, dotándonos

En realidad, aunque la estrategia de fundamentación filosófica de los derechos cívicos sea diferente, el resultado final es, cuando menos, similar; teniendo además la virtud de hacer visible la íntima imbricación de la etapa posconvencional con la filosofía política.

7. En su paso de la Teoría Crítica a su propia Teoría de la Acción Comunicativa, Habermas se ve en la necesidad de reformular los postulados epistémico-metodológicos de las ciencias sociales, donde uno de los pilares básicos en la transferencia de los «intereses cognitivos» a las "pretensiones de validez discursivas», será su reelaboración de los tres mundos cognitivos de Popper en: «(1) el mundo objetivo (como conjunto de todas las entidades sobre las que son posibles enunciados verdaderos); (2) el mundo social (como conjunto de todas las relaciones interpersonales legítimamente reguladas), y (3) el mundo subjetivo (como totalidad de las vivencias del hablante a las que éste tiene un acceso privilegiado)»; ver Habermas, J., Teoría de la Acción Comunicativa, vol. I. (TAC-I), Taurus, Madrid, 1992, p. 144. La tesis de Habermas es que las sociedades primitivas no conseguían distinguir entre los tres mundos citados, mientras el incremento de racionalidad procedente de la evolución social habría permitido una progresiva diferenciación de estos mundos como problemas discursivo-cognitivos específicos y autónomos entre sí.

8. Sobre el concepto de «imagen del mundo» de Jaspers, se puede consultar su libro: Psicología de las concepciones del mundo, Gredos, Madrid, 1967, p. $191 \mathrm{s.}$ 
para su percepción cognitiva, de un cierto sentido de orden 9 . Jaspers, concretamente, distingue tres grados de interpenetración entre la imagen de mundo y la experiencia cognitiva: 1) el mundo vivido, como aquél más próximo a la actividad vital de un individuo, del que incluso no se tiene una representación mental muy clara pero que es absolutamente eficaz y fiable para la acción ${ }^{10}$;2) el mundo objetivado, como aquellas representaciones sobre el mundo que hemos podido experimentar como ciertas alguna vez en nuestras vidas, aunque no tengan una relación de proximidad vital en la actualidad, y 3) el mundo meramente conocido, del que se nos ha provisto algún tipo de información pero que no hemos podido comprobar personalmente.

La interpretación que realiza Weber de este concepto desplaza su significado sociológico hacia una especie de medida de la racionalidad sociocultural, pero respetando al mismo tiempo la doble conceptualización de Jaspers entre representación y vivencia del mundo. Una imagen del mundo, en consecuencia, no es un producto intelectual meramente abstracto, como lo pueda ser una fórmula matemática, sino que vendría a dejar constancia de la necesidad del hombre de «vivir» dentro de un mundo «instituido de significado», y de su capacidad «imaginativa» para sumergirse y vivir dentro de los propios mitos que previamente ha creado ${ }^{11}$.

El mismo Jaspers ya se enfrentó a la tarea de dotar de «sentido» a la historia practicando cortes que viniesen a señalar las rupturas entre estas «imágenes del mundo», forjando para dicho propósito el concepto de «tiempo eje» ${ }^{12}$. La pregunta clave que se formula Jaspers es bajo qué criterio se puede acotar dónde comienza la historia propiamente dicha, es decir, cuando tendría "sentido" para el hombre hablar de su propia historia como hombre. Frente a la concepción común que viene a establecer su inicio en las primeras fuentes escritas (y que nos llevaría a asumir una cuestión de método de trabajo de fuentes para diferenciar la historia de la prehistoria), Jaspers prefiere establecer este «tiempo eje» (frente, por ejemplo, a la fecha de nacimiento de Jesús de Nazaret como «tiempo eje» de los cristianos) en alguna característica que sea común para todos los hombres, esto es, que vislumbre, dentro del desarrollo sociohistórico, una pauta de «universalidad» a partir de la cual el hombre pueda definirse a sí mismo con un carácter genérico. Para Jaspers, este corte profundo en la historia no sería otro que el proceso espiritual acaecido entre el 800 y el 200 antes de Cristo, gracias al cual habrían nacido,

9. Con la definición de «imagen del mundo», los conceptos de conocimiento y acción aparecen íntimamente imbricados. Consecuentemente, aquí el conocimiento hay que entenderlo como un conocimiento para la acción, del mismo modo que sólo a través de la acción con el mundo se puede adquirir nuevo conocimiento.

10. Una categoría sociológica procedente de la fenomenología que se aproxima bastante a este concepto es la de "mundo de la vida».

11. Ver CASTORIADIS, C., La institución imaginaria de la sociedad, vol. 2, Tusquets, Barcelona, 1989.

12. Ver Jaspers, K., Origen y meta de la historia, Alianza, Madrid, 1985, p. 19-43. 
en diferentes partes del mundo (China, India y Occidente), las religiones universales ${ }^{13}$.

Quien mejor habría sabido beneficiarse de esta conceptualización del tiempo eje de Jaspers no sería otro que S.N. Eisenstadt. En su artículo titulado "The Axial Age Breakthroughs: their Characteristics and Origins» ${ }^{14}$, Eisenstadt distingue entre tres tipos diferenciados de imágenes del mundo que se corresponden con las sociedades preaxiales, axiales y posaxiales. Las épocas pre-axiales serían aquéllas correspondientes al hecho fundacional de las sociedades, que se instituyen en el mismo momento de «simbolización sagrada» de la realidad natural y social de la práctica ritual mágico-religiosa. La sociedades axiales serían aquéllas que crean una ruptura de niveles en la significación de la realidad, entre un mundo profano y un mundo sagrado, y que se corresponderían, fundamentalmente, con la época de instauración e implantación de las grandes religiones universales. Por último, las sociedades posaxiales serían aquéllas en las cuales, en virtud de una secularización de los universos simbólicos de vivencia, se manifiesta una disolución de las grandes metanarrativas sagradas a favor, en los términos utilizados por Weber, de una creciente racionalización sociocultural de esferas de valor ${ }^{15}$.

Las páginas restantes de este artículo van a tener por objetivo perfilar, para cada una de estas etapas, las características definitorias de la racionalidad de sus respectivas imágenes del mundo junto con sus particulares moralidades sociales.

13. Jaspers distingue también una segunda ruptura histórica producida por el progreso técnico en torno al siglo XVIII, que, con el desarrollo de la racionalidad científica, daría paso a la imagen moderna del mundo; ver ibídem, p. 139 s.

14. Ver en Eisenstadt, S.N. (ed.), The Origins and Diversity of Axial Age Civilizations, State University of New York, Albany, 1986.

15. No habría que confundir la conceptualización de las «edades axiales» de Eisenstadt (importada del concepto "tiempo eje» de Jaspers), con el concepto de "principios axiales» de D. Bell. Para éste último, los "principios axiales» son principios de organización social que, por una parte, se refieren a los «ejes» que utilizamos para ordenar nuestros conocimientos y percepciones del mundo (en esto se podrían equiparar a las divisiones centrales que generan los «sistemas sociales» en Luhmann), y, por otra parte, en similitud con la «estructura estructurante» de Bourdieu, a "principios de estructuración» de la acción social (se puede consultar al respecto: D. BELL, El advenimiento de la sociedad postindustrial, Alianza, Madrid, 1991, p. 24 s.). El desarrollo de la teoría de D. Bell tiende a primar esta segunda concepción frente a la primera, como se manifiesta en su estricta aplicación a lo que previamente Parsons había conceptualizado como «sistemas de acción: la estructura social (economía, tecnología, trabajo), la política (poder legislativo, ejecutivo y judicial) y la cultura (el ámbito de la expresión simbólica y de la subjetividad). El primer acercamiento conceptual si podría apuntar hacia su vinculación con las «imágenes históricas del mundo", y en cierta manera así se reconoce al asociar los principios axiales a una nueva forma de concebir la organización y la racionalidad social en las emergentes sociedades posindustriales, pero no existe por parte de D. Bell una formulación explícita en este sentido. Curiosamente, Habermas tomará buena nota de dicho término en su «Reconstrucción del materialismo histórico», para sustituir, emulando el propósito de higiene ideológica de D. Bell, los conceptos marxistas de «modo de producción» e «infraestructura» por el concepto de "principios de organización». 


\section{El estadio moral preconvencional de las sociedades históricas preaxiales}

Hablar de una realidad imaginada como una dimensión mágica es, quizás, la principal característica común que se le puede adjudicar a la imagen del mundo preaxial. Esta «otra realidad» se experimenta, en estimación de K. Otto ${ }^{16}$, como un numen fantástico y sobrecogedor, cuya presencia produce una súbita interrupción en la familiar percepción de la realidad, a través de cuya abertura el hombre puede intuir la presencia de lo sagrado ${ }^{17}$, es decir, de la misma "voluntad de ser» del mundo que se le enfrenta bajo la forma de una potencia o numen sobrenatural.

El término que finalmente ha acabado por imponerse en la antropología para designar esta realidad imaginada del pensamiento mágico no es otro que mana. Si bien dicho término procede originariamente de la investigación de campo que Codrington realizó en Melanesia, sería equiparable, en estimación de diferentes escuelas antropológicas, con otros términos que se suelen utilizar en otros lugares del planeta para describir la esencia vital del universo mágico. A través de la categoría del mana, la cognición humana, por intermediación de la imaginación, habría yuxtapuesto a la facticidad material otra realidad de carácter ideal, en la que se podría llegar a dar una explicación causal a los fenómenos naturales en términos mágicos. El mana, en consecuencia, comparece como una "cuarta dimensión" de todas las cosas que se encuentran en la naturaleza, al tiempo que se proyecta como un éter mágico que conecta todas las cosas entre sí y permite, por ejemplo, la acción mágica a distancia ${ }^{18}$. El hombre sería capaz de penetrar y actuar en esta "otra» realidad a través de diferentes artificios mágicos, que bien le pondrían en contacto con su propio mana o fuerza espiritual, o bien con potencias que viven en dicha realidad sobrenatural y que puede utilizar como aliados ${ }^{19}$. De hecho, en muchas culturas llamadas "primitivas", uno de los deberes centrales de todo individuo consiste en descubrir su «gemelo espiritual» en la naturaleza mediante algún tipo de ritual de iniciación, a partir del cual podrá alcanzar una identidad social para el resto del grupo y ser considerado una persona adulta ${ }^{20}$.

16. Отто, R., Lo Santo, Alianza, Madrid, 1991; p. 31.

17. Eliade, M., Lo Sagrado y lo Profano, Labor, Barcelona, 1985, p. 18. Eliade bautiza como hierofanías a estas irrupciones de lo sagrado en el mundo.

18. Maus, M., Sociología y Antropología, Tecnos, Madrid, 1979, p. 125 s.

19. Los chamanes, quizás la expresión más pura del actor mágico, buscan estos «aliados» como forma de poder actuar en esta realidad, para, por ejemplo, curar enfermedades o provocarlas. Ver EliAde, M., El chamanismo y las técnicas arcaicas de éxtasis, FCE, México, 1986; Harner, M., La senda del chamán, Swan, Madrid, 1987; LevY-BruHL, L., La mitología primitiva, Península, Barcelona, 1978; RIES, J. (ed.), Los ritos de iniciación, EGA, Bilbao, 1994; AMODIO y JUNCOSA, (ed.), Los espiritus aliados: chamanismo y curación en los pueblos indios de Sudamérica, Abya-Yala, Ecuador, 1991.

20. LowIE, R.H., Religiones primitivas, Alianza, Madrid, 1983, p. 38 s. Por ejemplo, entre ciertas tribus aborígenes de México y Guatemala, este "doble» animal del propio espíritu del chamán es conocido con el mismo término con que se designa a la figura del chamán: el nagüal, en el que, bien sea en la forma de jaguar, ciervo, serpiente, cuervo, etc., el propio 
Los chamanes, como primeros especialistas o profesionales del mundo mágico, necesitan, para adquirir su condición, ciertos rituales que los hagan comulgar y saturarse de la energía del mana; rituales que en ocasiones requieren de mutilaciones físicas que se ofrendan a las potencias mágicas para conseguir su favor (es más común encontrar rituales iniciáticos en los que se experimenta un descuartizamiento simbólico, vivido a través de la imaginación con la ayuda de diferentes psicotrópicos, que representa la muerte de la condición mundana y el renacer en la realidad del universo mágico). Gracias a estos aliados mágicos, el chamán se encontrará facultado para operar en la dimensión mágica y ejercer funciones valiosas para el grupo como la de curanderos ${ }^{21}$. El mal, bien sea en la forma de desgracias, accidentes o enfermedad, se atribuirá a potencias o fuerzas invisibles que actúan sobre los hombres, y que en muchos de los casos se les adjudicará una procedencia humana en virtud de una manipulación mágica del mana conocida generalmente como «brujería» ${ }^{22}$. De este modo, en el pensamiento mágico, la principal forma de protegerse frente a la enfermedad o a los peligros inciertos (las contingencias inevitables de una vida en la naturaleza), es mediante talismanes, fetiches y rituales varios que atraigan un mana protector frente a las influencias malignas ${ }^{23}$, donde el mismo chamán se presentará ante el enfermo, por su indumentaria recargada de «objetos de poder», como un talismán que atrae sobre sí mismo las fuerzas benefactoras del $m a n a^{24}$.

De todos modos, la experiencia de lo sobrenatural, como choque cognitivo que habría impulsado el descubrimiento universal de esta realidad mágico-

chamán puede metamorfosearse; ver HARNER, M., La senda del chamán, Swan, Madrid, 1987. Sin ir más lejos, también se puede hacer referencia de las innúmeras leyendas de licantropía para explicar la inusitada inteligencia de ciertos lobos que sembraron el pánico entre pueblos de pastores y ganaderos europeos hasta épocas recientes (LÉVY-BRUHL, L., La mitología primitiva, Península, Barcelona, 1978, p. 73-101).

21. AmODIO, E.; JunCOSA, J. (comp.), Los espiritus aliados: chamanismo y curación en los pueblos indios de Sudamérica, Abya-Yala, Ecuador, 1991, p. 8.

22. En algunas sociedades como la azande, la causa de la enfermedad será achacada siempre a una acción de brujería, dónde la curación sólo será posible encontrando al hechicero o hechicera responsable. Ver EvANS-PRITCHAR, E.E., Brujería, magía y oráculos entre los azande, Anagrama, Barcelona, 1976, p. 83. Como bien analiza este reputado antropólogo, la creencia en brujería actúa como una forma de «solidaridad en negativo», es decir: «Puesto que los azande no saben quiénes son y quiénes no son brujos, suponen que todos sus vecinos pueden ser brujos y, por tanto, tienen cuidado en no ofender a ninguno de ellos sin causa justificada»; ver, ibídem, p. 128. Mari Douglas realiza una interpretación similar; ver Douglas, M.: «Brujería: el estado actual de la cuestión», en LloberA, J.R., Ciencia y brujería, Anagrama, Barcelona, 1988, p. 42-52.

23. La tesis de que la función básica de la magia, y en consecuencia la causa de su aparición, es la de proveer al hombre primitivo de una confianza y seguridad en la eficacia de sus actividades, envolviéndole en una especie de ilusión, consensuada colectivamente, sobre su capacidad de control de la naturaleza, goza de gran aceptación entre los teóricos comprometidos con un enfoque "psicologista», como puedan ser Wilhelm Wundt, Lowie, Crawley, Radin, Goldenweiser, Driberg, Firth, Van Der Leew, Williams James y el mismo Freud.

24. Eliade, M., El chamanismo y las técnicas arcaicas de éxtasis, FCE, México, 1986, p. 130 s. 
imaginaria, tendría por origen una ruptura perceptiva de la realidad mucho más básica y visceral que su posterior socialización como un espacio de actividad sagrada o su reinterpretación cultural en relatos mitológicos ${ }^{25}$. Así, por ejemplo, Eliade hablará de las «hierofanías» como vórtices por los que la realidad sobrenatural se manifiesta en el mundo natural ${ }^{26}$, y Otto dirá que el terror que despierta la conexión con «lo absolutamente otro» se transforma en un aura de majestuosidad y respeto reverente ${ }^{27}$, definida por James como «un temblor entusiasta de adhesión» ${ }^{28}$. Marett, apoyándose en trabajos de campo sobre los melanesios, destacará también el carácter sobrenatural de ciertas experiencias a las que se ve sometido el hombre primitivo, que tienen por resultado el crear una ruptura en su percepción cognitiva capaz de suscitarle la idea de un doble espiritual para todas las cosas: el mana ${ }^{29}$.

Desde mi punto de vista, quien mejor ha sabido realizar una interpretación de estos lapsus perceptivos de la realidad con pretensiones científicas, no ha sido otro que J. Campbell. Apoyándose en la teoría de los «isomorfos» de Wolfgang Köhler, Campbell asume que los animales se adaptan a su entorno de manera inmediata y con la certeza del reconocimiento innato, de forma que, en cierta manera, tiene que existir un mecanismo osmótico de transferencia entre la conducta de adaptación al entorno medioambiental por mediación de isomorfos y el proceso de evolución-selección genética ${ }^{30}$. Desde la biología del comportamiento animal, se designa esta preprogramación genética como «mecanismos innatos de liberación» frente a señales-estímulo que desencadenan una reacción instintiva ante circunstancias que nunca antes habían sido experimentadas, como por ejemplo el impulso de huida ante el avistamiento de un depredador ${ }^{31}$.

La función básica de los rituales mágicos sería, precisamente, la de revertir estas tendencias instintivas preprogramadas, canalizando y controlando, mediante rutinas cognitivas ritualizadas, las pulsiones emocionales que liberan diferentes estímulos procedentes de la realidad natural. Esta primera forma de normatividad mágica supondría un hito en la evolución de las especies, al pre-

25. Más adelante ofreceremos una diferenciación entre las categorías de «lo sobrenatural» $\mathrm{y}$ «lo sagrado», que la sociología durkheimiana colaboró en fundir en una categoría única para favorecer la interpretación religiosa del fenómeno.

26. Eliade, M., Lo sagrado y lo profano, Labor, Barcelona, 1985, p. 18.

27. Отто, R., Lo Santo, Alianza, Madrid, 1991, p. 31.

28. James, W., Las variedades de la experiencia religiosa, Península, Barcelona, 1994, p. 46.

29. Marett, R.R., Threshold of Religion, Methuen \& Co. LTD., Londres, 1979, p. 15 y s.

30. Campbell, J., Las máscaras de Dios, Alianza, Madrid, 1991, p. 51.

31. Tal y como lo describe Campbell: «Polluelos con las cáscaras de los huevos todavía pegadas a sus colas se precipitan bajo cubierto cuando un halcón vuela por encima, pero no cuando el pájaro es una gaviota o un pato [...] La imagen del enemigo ya está durmiendo en el sistema nervioso, y con ella la reacción bien comprobada. Además, incluso si todos los halcones del mundo desaparecieran, su imagen continuaría durmiendo en el alma del polluelo»; ibídem, p. 52. Para Campbell, los arquetipos jungianos tienen una naturaleza idéntica a la imagen del halcón en el sistema nervioso del pollo, es decir, que serían isomorfos incorporados a nuestra herencia genética, ver ibídem, p. 53. 
sentarse como un mecanismo de descarga emocional-instintivo que permite regular o reprogramar socialmente la conducta de los hominidos, teniendo como principal rendimiento cultural una significación simbólica de la realidad.

La equiparación de esta primera forma de normatividad mágica con la moral preconvencional se podría apoyar en tres características comunes. En primer lugar, la conducta en la etapa psicológico-evolutiva preconvencional, está altamente ritualizada, es decir, que el niño sentirá la necesidad de repetir continuamente algún tipo de acción que haya creado por sí mismo o que haya tomado prestada de un modelo externo por el propio placer que le proporciona su repetición, donde la creación de rutinas le va a crear la sensación de un mundo ordenado y familiar frente al abismo cognitivo de una totalidad sin cierres perceptivos temporales ni espaciales. La ritualización de algún tipo de acción, al igual que los rituales mágicos, tiene la virtud de crear una «ilusión de control» y orden sobre el espacio cognitivo en el que se ejecuta ${ }^{32}$. En segundo lugar, la percepción de la realidad está "ego-centrada»: el sujeto no sabe diferenciar adecuadamente entre su realidad interna y su realidad externa, creyendo que puede influir y controlar la segunda como si se tratara de su realidad interna. En las sociedades preaxiales, el actor mágico tendrá la convicción de que puede influir e imponer su voluntad sobre la voluntad de ser de la realidad natural, y que ésta puede ser manipulada a través del ritual mágico. Y por último, en tercer lugar, en correspondencia con el segundo estadio de la moral preconvencional, el actor mágico se pone en un mismo plano de igualdad con las potencias mágicas sobre las que pretende influir, estableciendo con las mismas una especie de contrato de contraprestaciones mutuas ${ }^{33}$.

32. Ver, por ejemplo: Giddens, A., Modernidad e identidad del Yo, Península, Barcelona, 1995, p. $55 \mathrm{~s}$.

33. Existen dos corrientes explicativas en torno a la función del sacrificio en las sociedades primitivas. La primera de ellas es la Teoría de la Comunión, de Robertson Smith, por la que se veían los sacrificios como una fiesta en la que comían juntos dios y sus adoradores, manifiesta en las «religiones» totémicas, donde la sangre derramada del animal tótem sacrificado y comido era al mismo tiempo la sangre de la tribu que lo degollaba (la del antepasado fundador) y la del dios del clan. La segunda es la Teoría del Don, defendida por Tylor y Spencer, donde la vida sacrificada es una ofrenda a los dioses para apaciguarlos y obtener su favor. Hubert y Mauss, lejos de considerar estas dos teorías como antagónicas, resaltarán sus virtudes individuales, donde, según la teoría de la comunión, el sacrificio representaría un puente comunicativo entre lo sagrado y lo profano por mediación de una víctima propiciatoria, por la que sería posible pasar de una unión en el plano material a otra en el plano moral; y donde el don entregado a las potencias espirituales sería equivalente a una relación contractual entre personas, por la cual se "ata» en un compromiso de devolución (de carácter moral), mediante una transferencia de mana (que aquí actuaría como «moneda» de cambio), a dichas potencias, convirtiéndolas en benéficas. Como resulta manifiesto, el acento que queremos resaltar del sacrificio en nuestro texto es el del compromiso contractual, que, como el mismo Durkheim no se cansará de afirmar, tiene una naturaleza moral para los individuos, pues su ruptura con las reglas de vida expresadas en los tabúes contractuales de los fieles para con sus potencias del orden tienen consecuencias extremadamente graves, expresadas en la condición de «infortunio" $\mathrm{y}$ "contaminación enfermedad». 
Aunque por el momento, con la finalidad de alcanzar una mayor claridad expositiva, hemos mantenido la hipótesis de que el pensamiento mágico tiene su origen en una experiencia personal con el imaginario, es obvio que en todos los registros etnográficos conocidos siempre aparece, en mayor o menor medida, íntimamente imbricado con alguna cultura originada en la comunicación lingüística. Sin embargo, el lenguaje traspasaría la frontera de ser un mero medio de comunicación para abrir a la conciencia humana hacia un nuevo universo de sentido, donde el verbo va a adquirir la virtud de producir un "bautismo ontológico» sobre la realidad natural. Como consecuencia, el lenguaje y el orden natural aparecen en un mismo plano de realidad, que se manifiesta en los rituales mágicos como elementos intercambiables de una misma esencia ${ }^{34}$. El mana, como categoría del pensamiento mágico, sería, en cierta manera, aquello que todavía no tiene un nombre, o, como destacarían Mauss y Lévi-Strauss, la designación "comodín» para lo innombrable ${ }^{35}$, y por ello, por la dimensión amorfa que señala Mary Douglas, como algo potencialmente peligroso ${ }^{36}$. Tal y como recoge Mauss de los registros del padre Thavenet sobre las tribus algoquinas, manitu (término similar al mana de los melanesios) «[...] designa todo ser que no tiene todavía un nombre propio, que no es todavía familiar. Una mujer decía que tenía miedo de una salamandra, que era un manitu, y se reía de ella al decirle cual era su nombre» 37 .

El principal rendimiento cognitivo del lenguaje no va a ser otro que producir una racionalización del universo "nombrado-conocido", provocando una confortable sensación de control sobre el mundo que posibilita la acción sobre el mismo ${ }^{38}$. Por el contrario, todo aquello que escapa al control de la acción humana se convierte en una incierta amenaza que se atribuye a un numen, mana o manitu con voluntad propia. El mundo del imaginario y el mundo creado socialmente permanecen así en una perpetua confrontación, donde, sin embargo, siempre existirá una tendencia del «imaginario social» por colo-

34. Este hecho se puede constatar en las propiedades mágicas que en todas las culturas se atribuyen a los nombres de las cosas. Por ejemplo, HORTON, R., «El pensamiento tradicional africano y la ciencia occidental», en LlOBERA, J.R., Ciencia y brujería, Anagrama, Barcelona, 1988, p. 93 s. Cassirer, E., Esencia y efecto del concepto de simbolo, México, Fondo de Cultura Económica, 1989, p. 30 s. y 80 s.

35. LÉVI-STRAuss, C., "Introducción a la obra de Marcel Mauss», en Mauss, M., Sociología y antropología, Tecnos, Madrid, 1979, p. 40-41.

36. Douglas, M., Pureza y peligro, Siglo XXI, Madrid, 1991.

37. Mauss, M., Sociología y antropología, Tecnos, Madrid, 1979, p. 127.

38. Como ya hemos señalado, la experiencia cognitiva que abre la percepción de una imagen del mundo, siempre procede de las posibilidades de acción sobre ese mundo. De ahí que, para enfrentarse a lo desconocido, el hombre tenga que «inventar» una acción mágica que le permita asimilar y crearse una ilusión de control sobre los riesgos que escapan a su acción física. Sobre la percepción de la contingencia y el riesgo en diferentes imágenes del mundo, ver: BERIAIN, J., "La contingencia como valor propio de la modernidad", en La lucha de dioses en la modernidad, Anthropos, Barcelona, 2000, p. 25-101. 
nizar el «imaginario radical» abierto a lo desconocido ${ }^{39}$. El pensamiento mitológico comparece así como la primera forma de institucionalización del imaginario social, como una primigenia cristalización del magma de significaciones posibles de la realidad del imaginario en relatos cosmogónicos que narran arquetípicamente como la realidad llegó a tomar existencia ${ }^{40}$. Los símbolos por los que ésta se materializa apelan al mismo tiempo a las dos formas de percepción de la realidad: a la racionalidad identitario-conjuntista de un lenguaje común y compartido entre una comunidad de comunicación; y a la ambigüedad propia del magma de significaciones del imaginario sobre el que se proyecta su transcendentalidad holística o sentido profundo, es decir, la hierofanía de su apertura a la realidad mítico-sagrada ${ }^{41}$.

Sin embargo, en su afán colonizador del imaginario, la realidad simbólica de las interpretaciones mitológicas no puede abandonarse en manos de cada navegante de la "otra realidad», presentando una tendencia creciente a una doxa defendida y monopolizada por unos especialistas en la materia. Estos especialistas, en su apropiación del mundo imaginario, tratarán de separar su ámbito de actuación del resto de actividades, creando un espacio social propio denominado «sagrado». El acceso a la trascendencia del universo mítico será canalizado de aquí en adelante por mediación del potencial katártico de los rituales colectivos, en los que, frente a la aisthesis de los chamanes y los místicos, dichos sirvientes de lo sagrado o sacerdotes oficiarán (y en algunos casos interpretarán) los dramas cosmogónicos para el resto de acólitos, como verdades reveladas e incuestionadas que, con fidelidad a la tradición, han sido heredadas directamente desde el pasado mítico ${ }^{42}$.

39. Celso Sanchéz Capdequí mantiene la tesis de un conflicto irresoluble, en el que el imaginario radical, como inconsciente colectivo de significaciones profundas, siempre emergería exitoso, cual Ave Fenix, de los intentos de colonización racional y encadenamiento prometeico por parte de los imaginarios sociales ortodoxos. Ver SÁNCHEZ, C., Imaginación y sociedad, Tecnos, Madrid, 1999. Ver también CASTORIADIS, C., La institución imaginaria de la sociedad, vol. II, Tusquets, Barcelona, 1989, p. 328-329.

40. Eliade, M., Mito y realidad, Labor, Barcelona, 1985, p. 12 s.

41. En opinión de Castoriadis: «[...] el mito no se reduce a la lógica y aun menos a la lógica binaria de los estructuralistas. El mito es esencialmente un modo por el que la sociedad catectiza con significaciones el mundo y su propia vida en el mundo, un mundo y una vida que estarían de otra manera evidentemente privadas de sentidos»; ver: Los dominios del hombre: las encrucijadas del laberinto, Barcelona, Gedisa, 1995, p. 71.

42. Cerrar el acceso al mundo imaginario-sagrado, como una prohibición de la comunicación sobre las experiencias del imaginario fuera de ese espacio social sagrado, no es sino una forma de defensa hacia la constante amenaza que supone para el orden social la apertura de interpretaciones del imaginario radical. Ver Luhmann, N., Teoría de la sociedad, Universidad de Guadalajara, México, 1993, p. 96-113; y también, Funktion der Religion, Frankfurt am Main, Suhrkamp, 1990, p. 118 s. En este caso, no sólo la comunicación sobre asuntos sagrados fuera de tiempo y lugar será percibida socialmente como una profanación y un sacrilegio, sino que la aventura individual de internarse por el imaginario sin la tutela sacerdotal también será considerada como una práctica aberrante de hechicería, que sólo puede tener por objeto establecer alianzas con las fuerzas demoniacas que habitan en dicha realidad.Ver WEBER, M., Ensayos sobre sociología de la religión, Taurus, Madrid, 1987, p. 249. 
Los rituales ceremoniales aparecen entonces, por ejemplo en estimación de Tambiah, como «sistemas culturalmente construidos de comunicación simbólica ${ }^{43}$, cuya función primordial no sería otra que la de confirmar los referentes estructurales del orden dogmatizado por los mitos en la realidad del imaginario, transportando a los acólitos, mediante un «juego del creer» ${ }^{44}$ canalizado por técnicas de katarsis colectiva ${ }^{45}$, hasta aquellas regiones del imaginario donde moran las potencias del orden. Estos rituales son, por lo general, una reactualización dramatúrgica de las verdades míticas, que de esta manera pueden ser vivenciadas en la realidad propia del imaginario como verdades "vivas», con pleno poder y vigencia. En los términos de Mircea Eliade, los rituales serían, en consecuencia, «actos ejemplares o arquetípicos» que permiten reintegrar la profanidad material del hombre en las regiones simbólicas de lo absolutamente real ${ }^{46}$; o, como lo expresaría Andrés Ortiz-Osés, el remiendo que sutura simbólicamente la fractura real entre la conciencia del hombre y el mundo que se le enfrenta como su realidad/alteridad ${ }^{47}$.

No obstante, la racionalidad presente en las imágenes míticas del mundo no es equiparable a la racionalidad científica que conocemos en la actualidad, puesto que, como ya hemos señalado, en ella se manifiesta también una gran influencia de la forma de percepción e interacción con el imaginario ${ }^{48}$. En estimación de Lévi-Strauss, el «pensamiento salvaje» o mitológico se nos presenta como una forma intelectural de «bricolage ${ }^{49}$ por la cual las estructuras mentales en bruto organizan diferentes acontecimientos para crear relatos míticos en los que se nos narra como la realidad viene a la existencia ${ }^{50}$. Lo que caracterizaría fundamentalmente el pensamiento mitológico es que parte de una

43. Tambiah, S.J., Culture, Thought and Social Action, Harvard University Press, Cambridge Mass, 1985, p. 128.

44. Durkheim, E., Las formas elementales de la vida religiosa, op. cit., p. 354 s.; HuIZINGA, J., Homo Ludens, Alianza, Madrid, 1972; CAmpBell, J., Las máscaras de Dios, vol. 1, Alianza, Madrid, 1991, p. $41 \mathrm{~s}$.

45. El repertorio de dichas técnicas en las llamadas «sociedades primitivas» es de lo más diverso y variopinto como para poder ofrecer un listado exhaustivo. Como mucho, podemos citar algunos de sus procedimientos, cuyo objetivo último es poner en «letargo» la conciencia de vigilia para ir introduciéndola, manteniendo el cuerpo "despierto», en un estado parecido al sueño, que se suele denominar como «trance». Entre éstos, que en muchas ocasiones aparecen combinados entre sí, se pueden citar: cadencias rítmicas y repetitivas de canto o mediante instrumentos «musicales» diversos; bailes con movimientos ritualizados que progresivamente se van haciendo al mismo tiempo más intensos y mecánicos; utilización de «imágenes» y objetos sagrados sobre los cuales se «centra» la capacidad intuitiva-imaginaria. Además, en muchos casos, se acompaña dicha actividad ceremonial con la ingesta de sustancias psicoactivas que por sí mismas producen estados alterados de conciencia.

46. Eliade, M., Tratado de historia de las religiones. Morfología y dinámica de lo sagrado, Cristiandad, Madrid, 1981, p. 56.

47. Ortiz-OsÉs, A., Las claves simbólicas de nuestra cultura, Barcelona, 1993, p. 55 s.

48. LÉVI-STRAuss, Antropología estructural, Paidós, Barcelona, 1995, p 233. Ver también en El pensamiento salvaje, FCE, México, 1984, p. 115.

49. Lévi-Strauss, C., El pensamiento salvaje, op. cit., p. 23.

50. Ibídem, p. 43. 
experiencia extática por el mundo del imaginario como fuente y forma de organización del conocimiento ${ }^{51}$, gracias a la cual el hombre podría llegar a intuir ese orden subyacente que está presente en la totalidad de la realidad ${ }^{52}$, aunque por el momento sólo pueda tratarse de una ilusión de orden que posibilita el que éste venga a la existencia ${ }^{53}$.

En el pensamiento mitológico, a través de su conexión con el imaginario como cosmos conjuntivo de experiencias y acontecimientos, la realidad es vivenciada como un espacio de experiencia único e indivisible, donde los tres mundos señalados por Habermas, el mundo objetivo-natural, el mundo normativo-social, y el mundo subjetivo, establecen un espectro indivisible de relaciones mutuas que vienen a ser plasmadas gráficamente en los relatos mitológicos. Los símbolos, lejos de representar significaciones unívocas, vienen entonces a expresar, misceláneamente, afinidades entre elementos tomados de la naturaleza, tabúes e identidades sociales, y experiencias vitales subjetivas ${ }^{54}$. Un ejemplo paradigmático de este tipo de símbolos lo podemos encontrar en los tótems ${ }^{55}$.

Los tótems son diferentes esculturas sobre elementos naturales, generalmente de madera, en los que se representa a algún animal o planta por media-

51. Ibídem, p. 48-49.

52. Según Lévi-Strauss, el pensamiento de los pueblos ágrafos se caracterizaría por «[...] un modo de pensar que parte del principio de que si no se comprende todo no se puede explicar nada, lo cual es absolutamente contradictorio con la manera de proceder del pensamiento científico, que consiste en avanzar etapa por etapa, intentando dar explicaciones para un determinado número de fenómenos y progresar, enseguida, hacia otro tipo de fenómenos, y así sucesivamente» (Mito y significado, Alianza, Madrid, 1990, p. 38).

53. LÉVI-STRAuss, C., El pensamiento salvaje, op. cit., p. 24-25.

54. Geertz hablará de una «descripción densa de la realidad» para describir este tipo de mixtura entre la acción física y la acción simbólica, donde el kosmos y el ethos sólo podrían entenderse mutuamente como la bóveda y las columnas que definen y sostienen respectivamente la realidad (una vivencia y presentificación del imaginario simbólico sobre el lienzo de la conciencia en el mundo). Ver GEERTZ, La interpretación de las culturas, Gedisa, Barcelona, 1990 , p. 23-24.

55. Sin lugar a dudas, quien ha tenido un mayor peso en la divulgación del totemismo como la forma originaria y más primitiva del fenómeno religioso no ha sido otro que E. Durkheim. El principal apoyo teórico de Durkheim en su conceptualización del totemismo procede de un libro de Robertson Smith que data de 1889 y que lleva por título: Lectures on the Religion of Semites: the Fundamental Institutions (Routledge, Londres, 1997); aunque el primero en señalar la posibilidad del totemismo como la forma de ideación religiosa más primitiva fue J. F. McLennan, en 1865, en su libro Primitive Marriage (Routledge/Thoemmes Press, Londres, 1998). No obstante, pese a reconocer una gran deuda y préstamo expositivo para con Durkheim, muchas de sus interpretaciones acerca del totemismo han sido desacreditadas desde el ámbito antropológico. De hecho, en la actualidad, especialmente después de las duras críticas de Boas, la antropología ha dejado en un preventivo suspenso esta relación unívoca entre el totemismo, como una forma de organización social por clanes, y la religión. Ver, por ejemplo: EVANS-PRITCHARD, E., Las teorías de la religión primitiva, Siglo XXI, Madrid, 1973; Eliade, M., Tratado de historia de la religiones, Cristiandad, Madrid, 1981; LÉVI-STrauss, C., El totemismo en la actualidad, FCE, México, 1986; LÉVISTrauss, C., El pensamiento salvaje, FCE, México, 1984; HARrIS, M., El desarrollo de la teoría antropológica, siglo XXI, Madrid, 1993. 
ción de algún tipo de grabado o pintura. Los tótems son, primigeniamente, las banderas por las que se identifica y distingue a una tribu o clan familiar de otra $^{56}$. Pero, al mismo tiempo, también representan una especie de pacto de la tribu con lo sobrenatural, es decir, un aliado imaginario que, como un dios, protege a toda la tribu de las fuerzas o potencias maléficas del mana; y que, en consecuencia, como lo manifiesta la compleja trama de normas a tabúes que reglamenta el protocolo de relación con el tótem, va a adquirir un carácter sagrado $^{57}$. El tótem es también el antepasado fundador del clan, que, como la segunda naturaleza de los chamanes, viene a otorgar su identidad a cada miembro del $\operatorname{clan}^{58}$, especificando además una serie de interdicciones rituales con el animal, planta o fenómeno físico representado ${ }^{59}$, que ningún miembro del grupo puede violar bajo pena de polución espiritual y enfermedad ${ }^{60}$. El tótem es, por ello, la «sangre» común que todos los miembros del clan portan en sus cuerpos, gracias a la cual se ratifica la unidad de un destino compartido que se remonta hasta el origen de los tiempos, y la garantía última del cumplimiento de las normas sociales bajo pena de excomunión. En las construcciones mitológicas se pondrán de manifiesto también los vínculos de afinidad entre los tótems y diferentes elementos de la naturaleza, solapando en un mismo esquema de clasificación cognitiva el mapa cosmológico del mundo y la organización social de parentesco en clanes ${ }^{61}$.

Eliade se referirá a esta hierofanía fundamental que supone el tótem, entre otras representaciones, como el axis mundi, es decir, el eje central u ombligo sobre el que gira el mundo conocido; una «abertura cósmica» que pone en relación el mundo profano con el mundo sagrado, a partir de la cual se irradian las fuerzas benefactoras del orden ${ }^{62}$. Y esta fuerza con la que aparece revestida la inmanencia de las figuraciones totémicas no es otra que la de su poder simbólico para remitirse a la trascendencia de una alteridad imaginada; en definitiva: a la fuerza imaginal ${ }^{63}$. Los ritos colectivos que surgen en torno al axis mundi, tengan o no forma de tótem, son los que permiten colonizar socialmente la fuerza o pensamiento salvaje de la imaginación para adecuarla a las necesidades de una progresiva complejidad en la organización social, gracias a cuya ayuda de carácter mágico-religioso, el hombre podrá inmolar sus propias inclinaciones fisiológicas y su programación instintiva en el altar de una común sociabilidad.

56. DurKheim, E., Las formas elementales de la vida religiosa, Akal, Madrid, p. 194.

57. Ibídem, p. 179.

58. LÉvy-BruHL, L., La mitología primitiva, Península, Barcelona, 1978, p. 14 s.

59. Algunos tótems representan fenómenos celestes como la lluvia, las estrellas y la noche, la tormenta, el Sol, la Luna, etc.

60. Durkheim, E., op. cit., p. 184; Douglas, M., Pureza y peligro, Siglo XXI, Madrid, 1991, p. $34 \mathrm{~s}$.

61. Durkheim, E.; Mauss, M., «De quelques formes primitives de classification: contribution à l'étude des représentations collectives", L'Année Sociologique, vol. VI, 1903, p. 1-72.

62. Eliade, M., Lo sagrado y lo profano, Labor, Barcelona, 1985, p. 38.

63. Beriain, J., «Imaginario social, politeísmo y modernidades múltiples», en Anthropos, 198, 2003, p. 55-56. 


\section{El estadio moral convencional de las sociedades históricas axiales}

Como ya vimos con Jaspers y Eisenstadt, la gran fractura que daría comienzo a la época axial sería aquella en la que se manifiesta una mayor racionalidad en la separación de los espacios entre lo sagrado y lo profano hasta dar lugar al problema de la teodicea. Si bien en la primeras manifestaciones religiosas en torno al axis mundi como origen de la creación ${ }^{64}$, ya se había producido una diferenciación primaria entre el espacio sagrado y el profano ${ }^{65}$, todavía no se había llegado a plantear la contradicción entre las relaciones de una esfera sagrada idealmente perfecta (los modelos arquetípicos de cómo la realidad debe comportarse) y un mundo profano imperfecto e injusto que continuamente se rebela ante los designios sagrados. Las explicaciones mitológicas que hasta el momento se habían producido eran fundamentalmente de dos tipos. En primer lugar, como nos diría J. Campbell, la de las potencias maléficas del caos que han sido desterradas de las estructuras de orden divinas para reaparecer como daimones nocturnos ${ }^{66}$, y, en segundo lugar, la de una especie de corrupción de la misma materia física que necesita ser fertilizada periódicamente por el mana sagrado gracias a la intervención del hombre en los rituales cosmogónicos ${ }^{67}$.

El proceso de racionalización que habría dado paso al problema de la teodicea habría tenido lugar a lo largo y ancho del mundo entre el 800 y el 200 aC, haciendo emerger en el seno de diferentes culturas lo que se conoce como religiones universalistas ${ }^{68}$. Esta nueva mentalidad religiosa, frente a las religiones

64. La primera pregunta que el hombre debe responderse a sí mismo para dotar de sentido al mundo en el que vive es, precisamente, cómo ha llegado éste a la existencia (mitos cosmogónicos), e inmediatamente después, cuál es el lugar del hombre dentro de ese mundo ya creado.

65. Lévi-Strauss patentiza, a partir de diferentes estudios de campo, como las aldeas de muchas tribus llamadas "primitivas» se organizan espacialmente en anillos concéntricos, en cuyo centro se coloca un símbolismo del axis mundi de carácter sagrado, circunvalado por tabúes de diferente tipo según la distancia al mismo y su grado de profanidad. Ver LÉVI-STRAUSS, C., "¿Existen las organizaciones dualistas?», en Antropología Estructural, p. 165-191.

66. CAmpbell, J., Las máscaras de Dios: mitología creativa, Alianza, Madrid, 1992, p. 198. Sobre los dioses diurnos y nocturnos, se puede consultar también: Durand, G., La imaginación simbólica, Amorrortu, Buenos Aires, 1971, p. 103-117; y también OrTIZ-OsÉs, A., La nueva filosofia hermenéutica. Hacia una razón axiológica posmoderna, Anthropos, Barcelona, 1986, p. 100-102.

67. DurKHeim, E., Las formas elementales de la vida religiosa, op. cit., p. 397 s. Esta última tesis es la que más se acerca a la racionalización del problema bajo la forma de una teodicea, entre un mundo corrupto y un ser idealmente perfecto, frente al carácter más mágico de la primera interpretación, que todavía tendrá alguna resonancia en las creencias religiosas como la figura de una representación personal del mal, que daría pie, por ejemplo, a la explicación de algunas enfermedades como posesiones demoníacas. La idea de la corrupción de la materia ya había sido explotada por algunas doctrinas religiosas previas (pero próximas a las universalistas) como la de Zarathustra, y recala especialmente en la idea del "pecado original» del judaísmo, del cristianismo y del islamismo.

68. El surgimiento de las religiones universalistas tuvo mucho que ver con el descubrimiento y el perfeccionamiento de la agricultura como forma de vida económica, y el feudalismo (el derecho a la tierra por servicios militares) como estructura social. Puesto que la riqueza y 
estatales de los viejos imperios como el egipcio o el babilónico, tendría la particularidad, y por ello se puede considerar universalista, de separar el ámbito profano de la administración político-económica (este mundo), del ámbito sagrado de lo imperecedero e idealmente perfecto y justo (el otro mundo) ${ }^{69}$.

De cualquier modo, indudablemente quien mejor ha sabido plantear la cuestión de la teodicea en términos sociológicos no ha sido otro que Max Weber. El problema de la teodicea, según este autor, adquiere relevancia social cuando se empiezan a racionalizar las diferentes figuraciones del axis mundi bajo la imagen de un dios creador supramundano, universal y todopoderoso. La pregunta que en tal contexto se suscitaría en el corazón de los creyentes no es otra de cómo puede ser compatible el infinito poder de un dios omnipresente y perfecto con el hecho de la imperfección e injusticia de un mundo que él ha creado y gobierna ${ }^{70}$. Ante esta tensión que representa el dualismo ontológico entre "este mundo» y el "otro mundo», todas las religiones universalistas se habrían propuesto buscar vías de encuentro que restaurasen el inicial equilibrio, aunque culturalmente difieran en sus interpretaciones o racionalizaciones. Fundamentalmente, en todas ellas existen dos tipos de soluciones que, por lo general, coexisten al mismo tiempo. La primera de ellas sería escatológica, bajo la forma de una profecía mesiánica en la que un héroe tocado con la gracia divina instaura en el mundo terrenal la parusia de un reino de perfección y justicia, al que sólo unos pocos elegidos por su virtud podrán tener acceso ${ }^{71}$. La segunda vía es la que realmente supone una diferencia cualitativa respecto a las viejas visiones del mundo. Con la creciente separación del ámbito profano de la política del ámbito sagrado de lo idealmente justo y perfecto $^{72}$, la vía escatológica va también perdiendo credibilidad de poder llegar a implantarse inminentemente en la realidad terrenal, desplazando la aspiración de participar en el reino mesiánico hacia un «más allá», en el que, a partir de un «juicio a los muertos», se pueda administrar una retribución o castigo divino acorde con los méritos o faltas de cada individuo ${ }^{73}$. Frente a los cultos

la subsistencia dependían de la posesión de la tierra, la única forma de garantizar su posesión frente a la invasión de pueblos nómadas era con una fuerte organización social militar.

69. En los términos de Habermas, gracias a la aparición de las religiones universalistas, habría sido posible una diferenciación racional-discursiva entre el mundo objetivo, por un lado, que por su relación con los asuntos mundanos-materiales aparece con un carácter profano, y los mundos social-normativo y subjetivo, por otro lado, que aparecen afincados en el ámbito sagrado de una ética y moral social de la salvación. Ver HABERMAS, J., Teoría de la acción comunicativa, vol. I, Taurus, Madrid, 1992, p. 99-105.

70. Weber, M., Economía y sociedad, FCE, Madrid, 1993, p. 412 s.

71. Los mitos cosmogónicos, en razón de la inercia degenerativa y corrupta que se le achaca a la vida terrenal, también incluyen casi siempre algún tipo de profecía escatológica en la que los antiguos dioses o héroes fundadores regresen para restaurar las viejas tradiciones y renovar las energías del mundo. Elíade, M., Mito y realidad, op. cit., p. $12 \mathrm{~s}$.

72. Frente a la economía de la edad de piedra de los pueblos nómadas cazadores y recolectores preaxiales, la organización agraria va a instaurar un orden estamental de origen militar, que por sí mismo constituye una fuente de sufrimiento y explotación, que cada vez choca más frontalmente con las aspiraciones de bienestar y justicia del mundo ideal sagrado. 
comunitarios y políticos de anteriores formas religiosas, aquí la posibilidad de salvación queda en manos de cada individuo, ya que, mientras siga fielmente las orientaciones éticas de un camino de virtud, no tendrá ninguna importancia su lugar de nacimiento ni su estatus social ${ }^{74}$.

En ambos casos, la columna vertebral que sostendrá tal racionalización de la teodicea es la idea de pecado y culpa. Con la caracterización de un dios perfecto como negación de la contingencia mundana, el mal atribuido a daimones en el pensamiento mágico también tiene que ser atribuido al dios creador $\mathrm{y}$, consecuentemente, interpretado desde dentro de la teología religiosa ${ }^{75}$. El sufrimiento ya no se atribuirá a una polución mágica accidental o a un acto de brujería (causa externa), sino más bien a la pérdida del favor divino como consecuencia de las propias faltas o pecados (causa interna como ruptura del pacto firmado con Dios para que proteja al fiel contra todo mal).

Las interpretaciones del pecado desde la teología religiosa encuentran dos tipos diferentes de explicación: la psicocognitiva y la doble naturaleza humana. Desde el punto de vista de la interpretación psicocognitiva, se puede considerar a S. Kierkegaard como el precursor de la misma, aunque con el inconveniente de ceñirse, en su análisis del pecado original, a la tradición judeo-cristiana. Según esta versión, antes del pecado original el hombre viviría en un estado de inocencia e ignorancia, dónde la psique humana estaría determinada inmediatamente por su naturalidad ${ }^{76}$. Con la instauración de la prohibición sobre la libertad instintiva de actuar en el mundo (Durkheim y Freud hablarían de la norma social), al hombre se le crea una noción sobre el bien y el mal actuar, pero que todavía no es conocimiento sobre el mismo, pues para que dicho conocimiento venga a la experiencia, se tiene que producir el pecado, la infracción de la norma o tabú ${ }^{77}$. La angustia se despertaría así como la "posibilidad de la libertad» frente a la prohibición ${ }^{78}$. Esta angustia objetiva estaría presente en el estado de inocencia edénico como una motivación hacia el conocimiento (en este caso, el conocimiento del mal), pero también, a par-

73. Weber afirmará que las categorías o ideas de cielo, infierno y juicio a los muertos alcanzan una resonancia universal en todas las religiones, incluso también en aquéllas anteriores a la época axial, como la egipcia.

74. Evidentemente, en religiones como la brahmánica, los estamentos sociales prescriben las obligaciones éticas de los individuos que pertenecen a cada una de ellas; pero la posibilidad de salvación religiosa como fin existencial, siempre queda en manos de cada individuo, con independencia de cual haya sido su condición de nacimiento.

75. LuHMann, N., Funktion der Religión, op. cit., p. 130.

76. KIERKEgaARD, S., El concepto de angustia, Espasa-Calpe, Madrid, 1982, p. 59.

77. Kierkegaard distingue entre una angustia objetiva (como concepto abstracto del mito del pecado original) y la angustia subjetiva (como experiencia del individuo). La transformación de una en otra pasaría por la transgresión de las prohibiciones, es decir, por la experiencia del pecado. Ver ibídem, p. 76-83.

78. Ibídem, p. 62. Kierkegaard reafirmará más adelante que: «en la angustia reside la infinitud egoísta de la posibilidad", es decir, lo indeterminado; ver ibídem, p. 81. En este sentido, el concepto de angustia cognitiva u objetiva sería similar al concepto construido con posterioridad por Festinger como «disonancia cognitiva». 
tir de la experiencia del pecado, como una angustia subjetiva que devuelve al infractor (mejor dicho, a su conciencia) al estado de la naturaleza, esto es, al no ser de lo indeterminado ${ }^{79}$. Esta angustia proveniente del pecado sólo podría superarse a través de la "salvación en la fe», es decir, de la creencia y práctica del bien como norma que determina al alma hacia un ser determinado en el mundo.

Para comprender este complejo desarrollo filosófico de Kierkegaard, nos tenemos que retrotraer a su particular configuración antropológica influenciada por Heguel, que divide al ser humano entre un cuerpo y un alma mediados por el espíritu. El alma, como expresión de la conciencia pura o en-sí, sólo podría autodeterminarse a sí misma a través del espíritu de una época, pues únicamente al prescribir el espíritu unas obligaciones éticas al alma ésta puede adquirir forma ${ }^{80}$. Por esta razón, la interpretación kierkegaardiana del pecado resulta excesivamente forzada en sentido cognitivo, aunque no por ello deja de ser interesante como marco de análisis de la verdad religiosa como un «dogma de fe» que es necesario acatar para mantener la salud mental y las aspiraciones de salvación de los creyentes (un ideal del yo salvífico), frente a la indeterminación de la disonancia cognitiva del no-ser (aquí el reconocimiento de la existencia del yo vendría apuntalado y garantizado institucionalmente a través de la salvación religiosa).

No obstante, la otra interpretación de la dualización de la naturaleza humana, tal y como realizaron Durkheim y Freud, nos provee de otro marco de análisis mucho más fructífero para abordar los sentimientos de culpa asociados al pecado. Así, frente a la libertad natural del mundo sensual, contaminado y contaminante de profanidad, se yergue la libertad superior del alma, que sólo en cuanto permanece "pura» puede aspirar al «re-ligare» con el mundo sagrado, es decir, a la salvación. La dualización de la naturaleza humana reproduce de este modo el dualismo ontológico del problema de la teodicea dentro del mismo individuo, y sólo a partir del mismo es como se puede llegar a racionalizar la idea de una salvación individual frente a la escatología de un juicio final colectivo. De esta manera, frente a la polución mágica como explicación del sufrimiento mundano en las sociedades preaxiales, la contaminación profana que impide al alma regresar a la pureza de lo sagrado sería interpretada como un estado de culpa por la pérdida de la gracia divina ocasionada por los propios pecados ${ }^{81}$. Y si la vida terrenal, pese a toda su concupiscencia, es por su sensualidad un

79. Al quebrantar la norma, ésta se anula, volviendo a dejar al individuo en su estado natural indeterminado.

80. Ver Temor y temblor, Tecnos, Madrid, 1995, p. 56 s. No obstante, la relación del hombre con lo divino, según este peculiar filósofo-teólogo, no se restringe a la «dimensión ética», sino que, en base a un ejercicio de reflexividad individual (que en sí mismo deberíamos concebir como posconvencional), cada cual deberá buscar un vínculo directo entre el alma y Dios (la verdad para mi), que Kierkegaard denomina como la «dimensión teológica». Esta nueva forma de búsqueda interior siempre vendría suscitada por la angustia ontológica del alma de encontrarse a sí misma en esta relación directa con lo divino, independientemente de lo que dicten los preceptos y deberes éticos del espíritu de una época. 
mundo de sufrimiento, la única libertad realmente posible (frente al sufrimiento) sólo puede encontrarse en la realidad espiritual de lo sagrado. La tentación de dejarse llevar por la libertad inferior de la sensualidad no hace otra cosa que alejar y condenar al alma al exilio de la verdadera felicidad y libertad espiritual, que no puede alcanzarse nunca en este mundo. En los términos de Freud, la instancia psicológica interna representante de las normas sociales (el super-yo) desatará un sentimiento reflejo de culpa cada vez que el individuo contravenga conscientemente dichas reglas que lo distancian, al mismo tiempo, de su ideal del yo (la salvación), creándole una angustia existencial que amenaza con el padecimiento eterno del infierno y la reprobación de las personas que encarnan la autoridad social y moral (los representantes de la autenticidad ontológica del ser como única forma de vida posible).

La idea del pecado, por consiguiente, nacería como concepto de la necesidad de buscar una explicación religiosa tanto a la angustia procedente de una indeterminación del ser (angustia ontológica o la necesidad de una vida auténtica y plena de sentido), como del sufrimiento de la vida en "este mundo" que se percibe como injusto (Weber), presentándose como el problema ético fundamental que, distanciándose del pensamiento mitológico, instaura axialmente la moral convencional ${ }^{82}$. Pero antes de entrar en que consistiría esta moral convencional y su correspondiente imagen del mundo, me gustaría resaltar algunas particularidades de la elaboración conceptual de M. Weber.

Desde su orientación metodológica de una sociología comprensiva, la única forma por la cual el ámbito de lo sagrado puede irrumpir en el mundo habitado por el hombre es mediante el carisma personal de un individuo singular. Aquí la hierofanía elemental es la del mismo portador del discurso de salvación: el profeta $^{83}$. Esta reducción metodológica, lejos de representar un obstáculo para el estudio del fenómeno religioso, tiene la virtud de ponernos sobre la pista de la comunicación social como elemento clave de análisis, que, a través de los medios de expresión de su "acción comunicativa», nos ofrecerá un registro oficial de los esfuerzos de racionalización de su correspondiente imagen del mundo. Esta racionalización no va a concluir con la muerte del profeta, sino que seguirá su curso en manos de sus discípulos en lo que Weber denomina un proceso de "rutinización del carisma», que no tiene otro objeto de ser que el de institucionalizar dentro de una organización social, fundamentalmente de carácter tradicional, el mensaje de salvación legado. En consecuencia, frente al carisma personal del profeta, el sacerdote reclamará su autoridad por estar

81. Weber, M., Economía y sociedad, op. cit., p. 416.

82. Habermas, J., Teoría de la Acción Comunicativa, vol. I, Taurus, Madrid, 1992, p. 267.

83. El profeta, aunque al igual que el mago o chamán actúa gracias a su don personal, se diferencia de éste último en que porta la revelación de una verdad de salvación frente al problema de la teodicea y el pecado. El chamán o mago profesional tan sólo sería un intermediario entre el ámbito profano y el mágico, situación que le permitiría la acción mágica de curación frente a la contaminación por malos espíritus o mana. Ver WebER, M., Economía y sociedad, op. cit., p. 356 s. 
al servicio de una tradición santa y encontrarse en disposición de distribuir los bienes de salvación gracias a su cargo institucional. En estimación de Weber, el objeto de la gestación de estas hierocracias ${ }^{84}$ es el de monopolizar para sí la administración del bien de la salvación religiosa, y regular su otorgamiento dándole la forma de una gracia sacramental ${ }^{85}$. Aunque el ritualismo sacramental sólo es una de las formas que toma el acceso a la salvación religiosa ${ }^{86}$, sí que, por sustraer al individuo la posibilidad de salvación por sus propios medios (especialmente, la búsqueda contemplativa o extática por las regiones del imaginario), se puede considerar como la más representativa de una moral convencional ${ }^{87}$.

Por consiguiente, podríamos retratar la moral convencional como aquélla que echa raíces en valores comunitarios sobre la "vida buena» como un camino ético de virtud con el que alcanzar el máximo fin realizativo de los individuos: la salvación; y como una organización social fundamentada en sólidos valores que tienen el respaldo de una tradición sagrada. Esta visión axiológica del mundo tiene la facultad de fundir en un mismo plano de realidad tanto la percepción de la vida social como del propio mundo subjetivo, de tal modo

84. Weber define las hierocracias como organizaciones de dominación que aplican como garantía de su orden la coacción psíquica de conceder o denegar la dispensa de bienes de salvación. Del mismo modo, define a las organizaciones eclesiásticas o iglesias como instituciones hierocráticas cuyos cuadros administrativos mantienen la pretensión al monopolio legítimo de la coacción hierocrática de manera permanente. Ver WEBER, M., Economía y sociedad, op. cit., p. 44.

85. Weber, M., Ensayos sobre sociología de la religión, vol. 1, Taurus, Madrid, 1987, p. 249.

86. Además del ritualismo sacramental, la salvación también se puede alcanzar, dependiendo de las doctrinas religiosas que le facilitan su racionalización como camino ético, a través de obras sociales o servicios a la comunidad, y a través del autoperfeccionamiento. Ver Weber, M., Economía y sociedad, op. cit., p. 419 s. En estimación de Weber, dado el problema de la teodicea entre "este mundo" y el "otro mundo", los requisitos para adquirir la condición de gracia de salvación dependen de las particulares «actitudes hacia el mundo» de las racionalizaciones religiosas, bien sea de rechazo o de aceptación del mundo terrenal. Ver Economía y sociedad, op. cit., p. 420-452. En las religiones de Oriente, como el budismo o el brahmanismo, la actitud predominante sería la del rechazo místico del mundo, que se manifiesta como un vuelo o huida del mundo; ver WEBER, M., Ensayos sobre sociología de la religión, vol. 2, Taurus, Madrid, 1987, p. 350. La forma religiosa más acabada de aceptación del mundo, que según Weber sería corresponsable, junto a otros factores, de la emergencia del capitalismo occidental, se correspondería con el ascetismo intramundano del protestantismo luterano y, especialmente, calvinista, ya que en la doctrina de la predestinación los creyentes únicamente pueden confirmar su estado de gracia de salvación a través de una vocación profesional en la que poder demostrar su condición como instrumento de Dios en el mundo; ver Economía y sociedad, op. cit., p. 450 s.

87. El más paradigmático instrumento del control hierocrático de la salvación lo encontramos en la posibilidad de confesión y perdón de los pecados de la doctrina católica cristiana; ver Economía y sociedad, op. cit., p. 920. Puesto que la naturaleza de todo individuo que no sea un santo es la de pecar, la única forma de salvación es que el momento de la muerte le alcance al creyente recién confesado. La racionalización de este tipo de dispensación de la gracia proviene de su administración ex opere operato, como un residuo de acción mágica por la que el sacerdote actúa como hierofanía que impone la gracia con sus manos; ver Economía $y$ sociedad, op. cit., p. 439 s. y p. 873. 
que, enlazados por una socialización en grupos compactos o, como diría Tönnies, comunitarios, la inmediatez de su familiaridad como «mundo de la vida» borra toda huella de su construcción social para aparecer como mundo instituido por la gracia divina. En su lectura weberiana, la forma de legitimación central de la moral convencional, frente a la carismática de los actores mágicos preconvencionales, sería la tradicional, que descansa en la creencia en la santidad de ordenaciones y poderes de mando heredados desde tiempos inmemoriales ${ }^{88}$. La obediencia de los individuos se prestará, en consecuencia, como un acto de devoción a las creencias compartidas en torno a una forma de vida correcta que ha sido dictada por las potencias sagradas de orden, y que, por consiguiente, son inviolables bajo pena de caer en desgracia del manto de protección divino y ser condenado a la desdicha eterna en la otra vida.

El mecanismo psicológico principal que ostenta la moral convencional para el control normativo de la conducta no es otro que el sentimiento de culpa. Tal y como pondrían de manifiesto S. Freud y E. Durkheim, la internalización de los valores axiológicos en los individuos como parte de su personalidad, es decir, de su identidad como personas reconocidas dentro de un grupo social, va a crear una instancia interna de autocontrol que inhibe las pulsiones instintivas a favor de aquéllas reconocidas socialmente como correctas. Desde el punto de vista de una moral convencional, esta internalización de valores en la instancia represora del super-yo adquiere la forma de un camino ético de salvación, que dispararía los sentimientos de culpa cada vez que la debilidad por atajar estoicamente la naturaleza carnal y pecadora del hombre lo alejaría de la redención para congratularse en la sensualidad mundana y la vanidad egoica. Como bien nos aleccionara Durkheim, la realización personal de los individuos aparece, en este tipo de moral convencional, supeditada a las necesidades del mantenimiento normativo de la conciencia colectiva, que, en virtud de su imposición sobre las conciencias individuales con la autoridad de lo sagrado, asegura la existencia y permanencia de la organización social misma, suscitando una solidaridad «interna» entre los sujetos sin la cual las necesarias desigualdades de la estructura social — como forma adaptativa de la especie a su entorno bajo el «modo de producción» agrícola - no podrían sostenerse.

\section{El estadio moral posconvencional de las sociedades históricas posaxiales}

Las sociedades posaxiales van a encontrar su lugar histórico, precisamente, en el proceso de modernización y secularización del orden normativo tradicional. Según la teoría de la secularización de Weber ${ }^{89}$, existirían cuatro pro-

88. Weber, M., Economía y sociedad, op. cit., p. 180.

89. El término secularización tendría su origen, precisamente, en la misma diferenciación axiológica entre un mundo sagrado y un mundo profano desgajado del anterior, donde el ámbito secular estaría referido a las distintas labores que llevaban a cabo los emisarios eclesiásticos en las actividades propias del mundo profano. 
cesos imbricados simultáneamente en la disolución de los sistemas de clasificación religiosos medievales hacia un mundo estructural y simbólicamente organizado en términos profanos ${ }^{90}$. El primero de ellos lo supuso la reforma protestante, que destruyó la pretensión de unidad de una iglesia universal ante el poder político, y que sirvió de paso para reforzar el ascenso y papel llamado a desempeñar por la burguesía al transformar la ética de la salvación de la llamada o vocación religiosa, por una ética secular del trabajo como vocación profesional — con la ética "intramundana» se desdibujan los límites axiológicos de los mundos sagrado y profano, pues la posibilidad de salvación únicamente puede ser alcanzada por mediación del trabajo en el mundo profano- - El segundo de estos movimientos fue la consolidación de estados públicos secularizados, que tuvieron su origen en una nueva clase de funcionarios dependientes de los monarcas absolutistas en la administración de diferentes monopolios - frente a las administraciones eclesiásticas feudales-, como pudieron ser, especialmente, el de los medios de sanción violenta, el de la recaudación fiscal y el de la monetarización dentro de un mismo territorio. En las posteriores revoluciones liberales, la nueva clase urbana burguesa y la intelligentzia ilustrada en torno al aparato administrativo monárquico, querrá asumir un mayor protagonismo político, teniendo que entrar en una confrontación directa con las iglesias - en buena parte «nacionalizadas» tras la emergencia de los estados absolutistas- en el aspecto de la legitimación del poder político. La tercera de las fuerzas que irrumpirán en este escenario histórico será el capitalismo como nueva forma de reestructuración económico-industrial, que promocionará, frente a la moral austera y diligente de los primeros burgueses procedente de la ética protestante, el espíritu de lucro y el valor del bienestar como sus principales valores existenciales para la "vida buena» ${ }^{91}$. Con su desarrollo en las sociedades de masas de producción estandarizada, el espíritu «materialista» del consumo y del despilfarro - como signo de distinción social — atravesará toda la sociedad, donde el dinero, como nuevo ídolo, se va a manifestar —en los términos de Burke y en virtud de su omnipresencia - como el «sustituto técnico de Dios» ${ }^{92}$. La última fuerza impulsora de la secularización comparecerá bajo la forma de una revolución científica, que primero al amparo de sociedades secretas bajo la vigilancia eclesiástica, y segundo como un "proyecto de Ilustración» de inevitable beligerancia contra la verdad revelada, será asumido por los propios estados absolutistas y liberales en su disputa con las

90. Para una interesante y sugerente visión del proceso de secularización en clave weberiana, se puede consultar: CASANOVA, J., Public religions in the modern world, University of Chicago, Chicago, 1994 (hay traducción española: Religiones públicas en el mundo moderno, PPC, Madrid, 2000).

91. Para esta transformación entre los dos tipos de burguesía por efecto del capitalismo, ver SOMBART, W., El burgués, Alianza, Madrid, 1972.

92. Ver Burke, K., A gramar of motives, Berkeley, 1969, p. 108-113; Simmel, G., La Filosofía del dinero, Instituto de Estudios Políticos, Madrid, 1977; BELL, D., Las contradicciones culturales del capitalismo, Alianza, Madrid, 1989, p. 33 s. 
instituciones eclesiásticas por el control de la «opinión pública» y la legitimación política, para finalmente conseguir arrebatar a la Iglesia su papel funcional como gestora del conocimiento social ${ }^{93}$.

A la par del desarrollo científico, de la especialización administrativa del poder político y económico, así como de la creciente preeminencia urbana en la configuración de las sociedades de masas modernas, va a eclosionar un proceso de estructuración social nunca visto hasta la fecha, como no es otro que la radicalización del proceso de la diferenciación funcional, y la emergencia de «medios generalizados de comunicación» para su regulación sistémica. La importancia de este fenómeno radica en una nueva forma de vinculación entre el individuo y la sociedad ajena a su definición normativa, y que se ubica exclusivamente en el mundo profano. Como bien intuyera Durkheim con su concepto de la solidaridad orgánica, y posteriormente Luhmann con su teoría de una evolución de la integración social desde los sistemas de interacción hacia los sistemas sociales, los vínculos que enhebran a los individuos a las sociedades complejas ya no vienen a articularse normativamente, sino funcionalmente ${ }^{94}$. La normatividad social pasa a ubicarse en un sistema social propio, como es el sistema jurídico, que de este modo se distancia de los sistemas de interacción simbólicamente estructurados del mundo de la vida; es decir, que las necesidades de reproducción social-normativa que mantienen la cohesion social, ya no se van a cargar sobre el sistema de la personalidad prescribiéndole unos moldes obligatorios de autorrealización bajo la forma de una ética de salvación. Precisamente, esta distancia - la que separa las necesidades de reproducción de los sistemas sociales de las necesidades de reproducción del sistema personalidad - es la que permitiría a los individuos descubrir su propia subjetividad mediante un ejercicio de autoobservacion reflexiva, pues al separarse el mundo social-normativo del mundo subjetivo, éste último puede desarrollarse «autónoma» e independientemente.

En los términos de Habermas, si en la moral convencional se habría producido una separación, en cuanto construcción de un conocimiento especializado, del mundo objetivo - conocimiento técnico-instrumental profano- respecto de los mundos social-normativo y subjetivo - conocimiento moral-religioso sagrado- - en la moral posconvencional se van a producir las condiciones sociales necesarias para que el mundo social-normativo y el mundo subjetivo se sepa-

93. Frente al proceso más calmado de reconocimiento público de las instituciones científicas en los países protestantes, en los países de herencia católica el proceso de «ilustración» va a adquirir un manifiesto y beligerante carácter antirreligioso, que se va a patentizar en la lucha por el control secular de la enseñanza pública. Sin ir más lejos, R.K. MERTON, en su conocido trabajo: Ciencia y técnica en la Inglaterra del siglo XVII, esbozará la afinidad electiva existente entre el puritanismo y el desarrollo científico.

94. Esta pretensión «orgánica» de la sociedad es una ambición que Luhmann no esconde para su teoría, donde la estructuración autopoiética de las sociedades en sistemas de conocimiento y acción, sin ningún tipo de anclaje normativo o simbólico que trascienda los propios mecanismos de regulación de los sistemas, se percibe como una realidad estructural-organizativa propia: la realidad orgánico-social. 
ren a su vez como esferas de conocimiento diferenciadas ${ }^{95}$. De este modo, el vínculo normativo que une a los individuos respecto de la sociedad se va a distanciar de cualquier pretensión "ético-existencial», aunque desde el punto de vista del poder va a necesitar todavía de un fundamento simbólico de legitimación "abstracto", que ya sólo puede ser reconstruido racionalmente en la dimensión de la ciudadanía política. La "moralidad pública», como un principio racional de la legitimación jurídico-política, y la «eticidad existencial», como proyecto axiológico de la vida buena sobre el que se articula la identidad y se estabiliza el sistema de la personalidad, se divorciarán para siempre en esferas independientes, donde si la moralidad pública de la integración entre individuo y sociedad va a aparecer simbióticamente aferrada a las estructuras de reproducción del sistema político, la eticidad existencial sufrirá una regresión hacia la privaticidad de los sistemas de interacción del mundo de la vida ${ }^{96}$.

En este escenario, la "moral pública» posconvencional se refiere a la necesidad de articular principios racionales de convivencia, tales como la justicia, para individuos que, procedentes de diferentes comunidades de creencia, se encuentran condenados a entenderse para vivir dentro de una misma socie$\mathrm{dad}^{97}$. Este entendimiento sólo podrá alcanzarse ya en la dimensión política, que define a los individuos, en cuanto ciudadanos, como sujetos racionales con igualdad de derechos (pero al precio de abstraer sus definiciones e identidades personales). Las diferencias que se pueden encontrar, por ejemplo, entre el republicanismo kantiano de Habermas y el liberalismo político de Rawls para dar respuesta a esta fundamentación filosófica de la moral pública postconvencional, que, entre otras aplicaciones, legitima a la democracia como arena política de encuentro entre sujetos racionales que se dotan de sus propias leyes de autogobierno, procede bien de sus preferencias hacia un modelo en concreto de democracia, o bien de su particular definición de la racionalidad práctica. No obstante, dada la complejidad del tema para tratarlo en el

95. Como ya se ha comentado, esta diferenciación habermasiana tiene su origen en la diferenciación de esferas de conocimiento y valor de Weber, que entiende que, en virtud de un proceso de racionalización sociocultural, en la modernidad se produce una separación de las anteriores definiciones cosmológico-religiosas de la realidad en tres esferas de conocimiento: la científica, la legal-normativa, y la artística — como expresión de la exploración de la propia subjetividad.

96. La división entre moralidad y eticidad se ha importado directamente de Habermas (frente a otros autores que invierten la semántica de los conceptos para describir fenómenos similares). Ver Habermas, J., "Moralidad y eticidad. Problemas de la ética del discurso», en Teorema, XIV, 3-4, p. 289-97; «Sobre moralidad y eticidad. ¿Qué hace racional una forma de vida?», Diálogo filosófico, no 9, p. 275-89 (recopilado en Aclaraciones a la ética del discurso, Trotta, Madrid, 2000, p. 35-51).

97. J. Rawls, en la reformulación de su teoría de la justicia en Liberalismo político, hace girar el problema fundamental de las sociedades modernas hacia la siguiente cuestión: «¿Cómo es posible la existencia duradera de una sociedad justa y estable de ciudadanos libres e iguales que no dejan de estar profundamente divididos por doctrinas religiosas, filosóficas y morales razonables?», en Political Liberalism, Columbia University Press, Nueva York, 1993, p. 4 . 
espacio disponible en este artículo, no podemos más que citar la cuestión para ulteriores desarrollos ${ }^{98}$.

Otra mención aparte nos merece la reconstrucción del ordenamiento psicológico de la personalidad e identidad en la modernidad tardía o posmodernidad, como consecuencia del desencuentro entre la moralidad pública y la ética existencial. Con el término de modernidad tardía o posmodernidad queremos referirnos al corte ideológico que se produjo en las sociedades occidentales avanzadas a partir de la Segunda Guerra Mundial, en el que se empezó a perder la fe en la idea de progreso y bondad de la razón técnica como proyecto ilustrado de la modernidad ${ }^{99}$, y que alcanzó su punto de inflexión con la caída del muro del Berlín y la desilusión o «agotamiento de las fuerzas utópicas» hacia modelos sociales alternativos al capitalismo ${ }^{100}$. En este contexto, en el que los individuos perderían supuestamente su capacidad para organizarse políticamente hacia proyectos o utopías sociales en las que depositar sus anhelos de autorrealización, se produciría una regresión narcisista hacia el yo ${ }^{101}$; regresión en la que además, dado el giro moral-cognitivo posconvencional, el ego ya no podría

98. Para una profundización en el problema de la construcción de una moralidad pública en la modernidad tardía, se puede consultar: J.C. Alútiz, Las fuentes normativas de la moralidad pública moderna. Las contribuciones de Durkheim, Habermas y Rawls. Tesis doctoral, Universidad Pública de Navarra, 2002.

99. El desencanto con la idea de progreso se produjo, al menos por parte de la Escuela de Frankfurt, a consecuencia de la barbarie nazi de los campos de concentración durante la Segunda Guerra Mundial, donde se hizo palpable históricamente como el progreso técnico por sí mismo no garantizaba en absoluto un progreso moral, sino que, incluso, podía degenerar en un ejercicio de terror organizado. Un primer desencanto hacia la idea de progreso vino primero de la mano de las organizaciones marxistas ante la imposibilidad de parar la Primera Guerra Mundial, donde se manifestó el fracaso de la hermandad mundial de trabajadores de poner freno a los intereses nacionalistas de carácter burgués (según su ideología).

100. D. Bell ya había profetizado, al igual que Nietzsche, la muerte de las ideologías en plena guerra fría, aunque haciendo referencia al mundo occidental. Ver BELL, D., El fin de las ideologías: sobre el agotamiento de las ideas políticas en los años cincuenta, Ministerios de Trabajo y Seguridad Social, Madrid, 1992; BELL, D., Las contradicciones culturales del capitalismo, Alianza, Madrid, 1977. Habermas se hará eco de este diagnóstico denominándolo, primero, "privatismo civil-familiar", y más tarde, tal y como se ha recogido, "agotamiento de las fuerzas utópicas»; ver Habermas, J., Problemas de legitimación en el capitalismo tardio, Cátedra, Madrid, 1999; Habermas, J., "Sobre la pérdida de confianza en sí misma de la cultura occidental», Revista de las Cortes Generales, tercer trimestre de 1984, p. 7-23 (recopilado como «La crisis del Estado de Bienestar y el agotamiento de las energías utópicas", en Ensayos políticos, Península, Barcelona, 1988, p. 113-34).

101. Ésta al menos sería la tesis básica de Lasch en The Culture of Narcissism, Abacus, Londres, 1980. Habermas y otros integrantes de la segunda escuela de Frankfurt, como C. Offe, ya habrían tratado la cuestión con anterioridad como un impulso al privatismo civil y un desencanto generalizado hacia la política. No obstante, su búsqueda de grupos sociales que mantuviesen en pie los proyectos utópicos de la emancipación del hombre, primero en las rebeliones estudiantiles de los sesenta y después en la emergencia de los nuevos movimientos sociales, pondría de manifiesto que todavía mantenían y mantienen vivas las esperanzas posmarxistas de un reino fraternal en el que el ser humano pueda encontrar las condiciones sociales de su autorrealización. 
recurrir para autodeterminarse a las directrices provenientes de una «identidad fuerte convencional». Así, la identidad ya no se va a sostener en estructuras normativas de carácter simbólico prescriptivas para toda una sociedad (y respaldadas fácticamente desde un orden social «tradicional»), sino que se va a fragmentar en una multiplicidad de opciones de valor sobre las que el individuo tiene la necesidad de elegir para definirse a sí mismo y su lugar en el mundo ${ }^{102}$. El proceso de socialización pasará de fundamentarse en un modelo freudiano de «identidades fuertes» (aquéllas que estructuran un super-yo en el sistema psicodinámico de la personalidad como una conciencia social «represora» o inhibidora de carácter interno que regula el material instintivo bajo "sentimientos de culpa»), a un modelo de «identidades frágiles o dinámicas» (aquéllas que se apoyan en la propia «autorreflexividad» racional-responsable de los individuos, que demandan de una continua interacción social en diferentes escenarios para performar y negociar definiciones «racionales» de situación y acción, reguladas sobre «sentimientos de vergüenza» y de reconocimiento personal) ${ }^{103}$.

En este nuevo modelo de vertebración de las identidades frágiles de la posmodernidad, el fenómeno más llamativo lo representa el traspaso en los mecanismos internos de control de la conducta desde los sentimientos de culpa, procedentes de un super-yo fuertemente estructurado sobre valores sólidos de vida, hacia los sentimientos de vergüenza, que ponen su acento en la necesidad de apuntalar constantemente el ideal del yo a partir de la aceptación interpersonal. Melvyn Fein, por ejemplo, teoriza sobre la posibilidad de una pri-

102. La falta de referentes valorativos externos en la construcción del yo es la que potencia las necesidades autorreflexivas para comprender nuestra psiquis. Giddens, por ejemplo, es de la opinión de que, en la actualidad, el psicoanálisis, lejos de representar una terapia clínica según el patrón clásico de una enfermedad que necesita curación, se ha convertido en un instrumento para desarrollar la capacidad autorreflexiva sobre la propia subjetividad. GidDens, A., Modernidad e identidad del yo, op. cit., p. 227-229.

103. El traspaso entre uno y otro modelo de la personalidad se patentiza en el cambio de las terapias psicológicas, donde el psicoanálisis va dejando su lugar, cada vez en mayor medida, a las terapias de grupo como la Gestalt. El problema fundamental del psicoanálisis en la era posmoderna se inscribe en el declive de la familia patriarcal y la crisis de la autoridad moral. En el psicoanálisis clásico, el terapeuta, en su papel de intérprete y guía de la reflexividad subjetiva, asumía la vieja tarea religiosa de sublimar las tensiones pulsionales inconscientes hacia las regiones conscientes del comportamiento social y moralmente tolerable. Para ello, se valía de su identificación con la figura paterna y/o con la del experto en salud mental, para investirse de la suficiente autoridad moral con la que hacer efectiva la dinámica interpersonal de "transferencia» que reforzase los mecanismos internos de sublimación. En la actualidad, por el contrario, no se puede defender ninguna pauta «moral» de comportamiento social como la más correcta elección de forma o estilo de vida, con lo que la mera autoridad moral (aunque ésta se defienda desde el nicho científico de una fe en la infalibilidad de los expertos) deja de convertirse en un referente legítimo para imponer ningún tipo de creencia externa al propio individuo. Además, el ideal de yo ya no se encuentra férreamente escoltado por el super-yo, puesto que éste último, ante la falta de valores vitales incuestionados, pierde sus contornos y relaja la guardia sobre las pulsiones libidinales. El ideal del yo, en consecuencia, carece de una identidad fuerte construida internamente, y necesita, para realimentarse, de una constante aprobación externa en sus relaciones interpersonales. 
vatización y degradación de la moral hacia el plano afectivo interpersonal, donde la calificación de buena o mala persona en las relaciones de grupo, independientemente de las creencias sobre el bien y el mal de cada individuo, es el principal referente para la evaluación y el control tanto de la propia conducta como de la de los demás ${ }^{104}$.

En resumen de lo dicho, podríamos concluir que, cuando el individuo ya no deposita sus expectativas de realización personal en un proyecto emancipatorio colectivo o en la salvación religiosa en el "otro mundo", se produce una regresión reflexiva hacia el yo que, en la indeterminabilidad de su identidad como proyecto ideal egoico, necesita de una constante aprobación social en diferentes planos de actividad (el trabajo, la familia, los amigos, etc.). Cuando los capitales personales ${ }^{105}$ y las capacidades comunicativas de un individuo no le proporcionan una imagen aceptable de sí mismo ante los demás (frente a la moral kantiana que defiende una misma dignidad e igualdad de estatus de todos los seres humanos en virtud de su misma naturaleza racional), el yo se encontraría expuesto a una crisis existencial de profundo calado, que necesitaría de una constante retroalimentación reflexiva sobre su subjetividad para autocorregir los mecanismos de defensa de carácter narcisita y neurótico desplegados como blindaje compensatorio. En estas condiciones, las «relaciones puras", basadas en la valoración de las personas como individuos únicos en virtud de su condición como seres humanos con un rico universo subjetivo de vivencia propio e intransferible, adquieren una importancia crucial e insustituible como apoyo a la identidad y autoestima, convirtiéndose también en la forma de terapia psicológica (grupos de apoyo) más adecuada para la reconstrucción y mantenimiento del yo.

\section{Conclusiones}

Después de este pequeño trayecto guiado a través de lo que se han venido a denominar «estadios morales de la evolución social», creo que, pese al riesgo

104. FeIn, M.L., Hardball without an Umpire: the Sociology of Morality, Praeger, Werport, 1997, p. 69-88. Fein también analiza los casos en los que ciertas personas, en virtud de su capacidad como líderes socioafectivos y su carisma personal, pueden manipular emocionalmente a un grupo informal para conceder a cada individuo una u otra calificación personal, lo que les permitiría tomar las riendas del grupo según más convenga a sus intereses personales. El problema de esta tesis es que subordina los problemas morales que atañen a nuestra conducta con los otros al mero desarrollo de una adecuada «inteligencia emocional», advirtiendo de paso del estado de indefensión moral-emocional de quien no consiga dicho desarrollo (el peligro de quedarse relegado o marginado en la negociación de las reglas que regulan la convivencia y las pruebas de estima en el grupo).

105. Denomino «capitales personales» a las diferentes capacidades de movilización y posesión de medios generalizados de comunicación, como el dinero, el poder, la verdad (cualificación técnico-profesional o parcela de "conocimiento experto" que se ocupa en la sociedad), y el amor (sex appeal). Dentro de la cultura anglosajona, heredera de la ética protestante del trabajo, a una persona que tuviera un déficit en todos y cada uno de estos capitales personales se le calificaría como un «fracasado» o un "perdedor». 
de convertirme en blanco de los escépticos sobre las virtudes de la modernidad o sobre el ocaso de la moralidad convencional (frente al hecho de la revitalización de las religiones y de los nacionalismos desafiantes al cosmopolitismo kantiano), he conseguido al menos el propósito de presentar un cuadro relativamente coherente sobre las diferentes configuraciones de la racionalidad sociohistórica y sus respectivas conciencias psicomorales. El retorno consciente (por propia elección) hacia comunidades de creencia religiosa o identidades nacionales, o incluso hacia comunidades posconvencionales tales como aquellas formadas por nuevos movimientos sociales en torno a valores posmaterialistas de vida, no hacen sino iluminar la problematización de la construcción de la identidad en la posmodernidad, mostrándose más como una estrategia defensiva del yo ante la tarea de reconstituirse reflexiva y continuamente desde dentro, que como una inercia de estadios racional-cognitivos anteriores.

Con la exposición que se ha realizado, tampoco se pretende defender un concepto de evolución moral vinculado al progreso, donde se produciría la paradoja de considerar las patologías provenientes del sostenimiento reflexivo del yo como un "avance moral» respecto de la conciencia moral religiosa. $\mathrm{Ni}$ tan siquiera que ésta última no pueda ser compatible con una forma de vida moderna y el perfecto desarrollo de las capacidades racionales. Lo que sí se quiere hacer constar es la ruptura con una visión del mundo de carácter tradicional, y la necesaria cohabitación de las elecciones personales ético-identitarias (aunque sean de carácter religioso), con otra definición más amplia y neutra de los individuos en cuanto ciudadanos con idénticos derechos políticos y de reconocimiento sobre su particular concepción ético-existencial. Y por necesidad, esta concepción más amplia, que abarque a todos los individuos de una sociedad por igual, tiene que considerarse como una «moralidad pública» compartida, que, en su fundamentación posconvencional, sea justa para todos, y, por consiguiente, igualmente válida y aceptable racionalmente para todos, aunque ya no venga respaldada por creencias existenciales e identitarias concurrentes en torno a un único modelo de la «vida buena».

Esta necesidad, a fin de cuentas, no sería sino una consecuencia directa de la descomposición de la moral entre una «moralidad pública» y una «eticidad existencial» en la modernidad, y que tiene por principal rédito una explosión y proliferación sin precedentes de formas y estilos de la «vida buena» concurrentes y coexistentes dentro de una misma sociedad. En estas condiciones, resulta de todo punto imposible llegar a determinar «valores» de vida o estructuras axiológicas que puedan obtener un reconocimiento generalizado por parte de todos los miembros de una sociedad — problema éste que ya había sido planteado por Nietszche, Baudelaire y Weber entre otros-, teniendo que recurrir a principios abstractos de racionalidad para fundamentar deontológicamente la «moralidad pública» que sostiene la validez cognitiva del orden normativo. Estos "principios de racionalidad práctica» podrían adoptar, según el criterio de tres autores representativos, tales como Durkheim, Habermas y Rawls, que precisamente han tomado como reto intelectual personal confeccionar una «mora- 
lidad pública» en la modernidad, diferentes formas como principios de legitimación de las estructuras de organización social. Para Durkheim, desde un enfoque convencional, la racionalidad pública sería ante todo una racionalidad cientifica, que daría lugar a un orden social planificado por expertos gracias al reconocimiento de su «autoridad racional» en sus respectivas materias disciplinares de conocimiento. Para Habermas, la racionalidad pública se plasmaría en una racionalidad comunicativa, que, desde una reconstrucción discursiva de carácter procedimental de la racionalidad práctica kantiana, define primero la autorrealización de la esencia humana en su capacidad reflexivo-comunicativa, para proyectarla después sobre el orden normativo público como un «fin realizativo» de ilustración crítica de la humanidad, tanto en sentido genérico (herencia marxista) como cosmopolita (Kant). Para Rawls, la razón pública sólo podría encontrar existencia en la dimensión política, donde, frente a la definición «privada» de los individuos en la sociedad civil a partir de alguna "doctrina comprensiva» (eticidad existencial), se produciría una definición público-política de las personas en cuanto ciudadanas abstractas, cuya principal fuente racional para sus «juicios reflexivos» se tomaría de una «teoría de la justicia» anclada en la tradición política liberal-contractualista.

$\mathrm{Al}$ mismo tiempo, en correspondencia con estos diferentes puntos de vista sobre la racionalidad pública práctica, y en virtud de la principal función de la «moralidad pública» de legitimar el poder político que estructura el orden normativo, cada uno de estos autores entiende que existen diferentes modelos de democracia para su expresión política, aunque concuerdan en que sólo a través de una forma de gobierno democrática se puede legitimar «racionalmente» el ejercicio del poder político. Para Durkheim, el ideario de la Tercera República Francesa contendría los dos rasgos principales de la racionalidad pública: en primer lugar, ser partidaria a ultranza de la racionalidad científica como forma de la organización social, y, en segundo lugar, ser defensora del individualismo humanista, definido a partir de una determinación «racional» de la naturaleza humana, que, a su vez, sería una consecuencia «ideo-lógica» de la organización científica de la sociedad. Para Rawls, el ideario que recoge más fidedignamente la naturaleza «racional» de la ciudadanía, es el Liberalismo Político, entendiendo esta naturaleza racional como un «juicio reflexivo» que se conforma en las condiciones pro tanto de la posición original en su «teoría de la justicia», y que dan lugar a un consenso constitucional como "cultura política» en la que se asienta la «razón pública». Para Habermas, la forma de gobierno del poder político más fiel a una racionalidad comunicativa no sería otra que la Democracia Deliberativa, que, frente al poder administrativo del sistema político, necesita del refrendo de la legitimación o validez de sus determinaciones por el poder comunicativo residente en la opinión pública, que, de este modo, mantendría un control «realizativo» sobre el orden normativo, reduciendo el riesgo de una estructuración sistémica a espaldas de la esencia «social-comunicativa» del ser humano.

En cualquier caso, se apueste por una u otra forma de racionalidad práctica con su consecuente expresión democrática, sí se puede concluir que, con 
la instauración de la modernidad, la moralidad pública traslada su residencia definitivamente desde el discurso religioso hasta el discurso político, sin que, pese a las resistencias de organizaciones político-religiosas con ambiciones de influencia pública, exista posibilidad alguna de dar marcha atrás. La existencia de sociedades que toman como principal fuente normativa del ámbito público una moral de carácter religioso, como podría ser el caso de bastantes países musulmanes, más que ponernos en la tesitura de un «choque de civilizaciones», nos apuntaría, según las tesis de este artículo, a un "choque de moralidades» (con sus respectivos grupos de intereses), donde, a priori, la moralidad posconvencional y sus agentes tendrían mayores posibilidades de prevalecer frente a la moral convencional al encontrarse mejor adaptados a las necesidades estructurales de las sociedades modernas y posmodernas.

\section{Bibliografía}

ALÚTIZ, J.C. (1998). «El problema de la integración en las sociedades modernas avanzadas». Estudios de Deusto, vol. 46/1, enero-junio.

- (2002). Las fuentes normativas de la moralidad pública moderna. Las contribuciones de Durkheim, Habermas y Rawls. Tesis doctoral. Universidad Pública de Navarra (http://www.unavarra.es/puresocles/c_tesis.htm).

AMODIO Y JUNCOSA (ed.) (1991). Los espiritus aliados: chamanismo y curación en los pueblos indios de Sudamérica. Abya-Yala, Ecuador.

BAUMAN, Z. (2002). «Para una teoría sociológica postmoderna» y «¿Existe una sociología posmoderna?». Acta Sociológica, n. ${ }^{\circ} 35$. México.

BECK, U. (1997). Modernización reflexiva. Madrid: Alianza.

BELL, D. (1989). Las contradicciones culturales del capitalismo. Madrid: Alianza.

- (1991). El advenimiento de la sociedad postindustrial. Madrid: Alianza.

- (1992). El fin de las ideologías: sobre el agotamiento de las ideas políticas en los años cincuenta. Madrid: Ministerio de Trabajo y Seguridad Social.

Berger, P. (1972). Para una teoría sociológica de la religión. Barcelona: Kairós.

BERIAIN, J. (2000). «La contingencia como valor propio de la modernidad». La lucha de dioses en la modernidad. Barcelona: Anthropos, p. 25-101.

- (2003). «Imaginario social, politeísmo y modernidades múltiples». Anthropos, n. ${ }^{\circ} 198$, p. $55-56$.

BURKE, K. (1969). A gramar of motives. Berkeley.

CAMpBell, J. (1991). Las máscaras de Dios. Madrid: Alianza.

CAMPS, V. (ed.) (1987). Historia de la ética (3 vol.). Barcelona: Crítica.

CaSANOva, J. (1994). Public religions in the modern world. Chicago: University of Chicago.

CASSIRER, E. (1989). Esencia y efecto del concepto de símbolo. México: Fondo de Cultura Económica.

CASTORIADIS, C. (1989). La institución imaginaria de la sociedad. Vol. II. Barcelona: Tusquets.

- (1995). Los dominios del hombre: las encrucijadas del laberinto. Barcelona: Gedisa.

Cortina, A. (2000). Ética minima. Madrid: Tecnos.

Douglas, M. (1988). «Brujería: el estado actual de la cuestión». En Llobera, J.R. Ciencia y brujería. Barcelona: Anagrama, p. 42-52.

- (1991). Pureza y peligro. Madrid: Siglo XXI. 
DURAND, G. (1971). La imaginación simbólica. Buenos Aires: Amorrortu.

DURKHEIM, E. (1982). La división del trabajo social. Madrid: Akal.

- (1992). Las formas elementales de la vida religiosa. Madrid: Akal.

EISENSTADT, S.N. (1983). Tradition, change, and modernity. Robert E. Krieger, Malabar.

- (ed.) (1986). The Origins and Diversity of Axial Age Civilizations. Albany: State University of New York.

Eliade, M. (1981). Tratado de historia de las religiones. Morfología y dinámica de lo sagrado. Madrid: Cristiandad.

- (1985). Lo sagrado y lo profano. Barcelona: Labor.

- (1985). Mito y realidad. Barcelona: Labor.

- (1986). El chamanismo y las técnicas arcaicas de éxtasis. México: FCE.

EVANS-PRITCHAR, E. (1973). Las teorías de la religión primitiva. Madrid: Siglo XXI.

- (1976). Brujería, magía y oráculos entre los azande. Barcelona: Anagrama.

FEIN, M.L. (1997). Hardball without an Umpire: the Sociology of Morality. Werport: Praeger.

Freud, S. (1993). Los textos fundamentales del psicoanálisis. Barcelona: Altaya.

GEERTZ, C. (1990). La interpretación de las culturas. Barcelona: Gedisa.

Giddens, A. (1995). Modernidad e identidad del yo. Barcelona: Península.

- (1997). Consecuencias de la modernidad. Madrid: Alianza.

Habermas, J. (1984). «Moralidad y eticidad. Problemas de la ética del discurso». Teorema, XIV, 3-4, p. 289-97.

- (1984). «Sobre la pérdida de confianza en sí misma de la cultura occidental». Revista de las Cortes Generales, tercer trimestre, p. 7-23 (recopilado como «La crisis del Estado de bienestar y el agotamiento de las energías utópicas», en Ensayos politicos, Barcelona: Península, 1988, p. 113-34).

- (1992). La reconstrucción del materialismo histórico. Madrid: Taurus.

- (1992). Teoría de la Acción Comunicativa, vol. I.y II. Madrid: Taurus.

- (1998). Facticidad y validez. Madrid: Trotta.

- (1999). Problemas de legitimación en el capitalismo tardío. Madrid: Cátedra.

- (2000). «Sobre moralidad y eticidad. ¿Qué hace racional una forma de vida?». Diálogo filosófico, n. ${ }^{\circ}$ 9, p. 275-89 (recopilado en Aclaraciones a la ética del discurso, Madrid: Trotta, 2000, p. 35-51).

Harner, M. (1987). La senda del chamán. Madrid: Swan.

HARris, M. (1993). El desarrollo de la teoría antropológica. Madrid: Siglo XXI.

HorTON, R. (1988). «El pensamiento tradicional africano y la ciencia occidental». En

LloberA, J.R. Ciencia y brujería. Barcelona: Anagrama.

HuizingA, J. (1972). Homo Ludens. Madrid: Alianza.

JAMES, W. Las variedades de la experiencia religiosa. Barcelona: Península.

JASPERS, K. (1967). Psicología de las concepciones del mundo. Madrid: Gredos.

- (1985). Origen y meta de la historia. Madrid: Alianza.

KIERKEGAARD, S. (1982). El concepto de angustia. Madrid: Espasa-Calpe.

- (1995). Temor y temblor. Madrid: Tecnos.

KohlBerg, L. (1992). Psicología del desarrollo moral. Bilbao: Desclée de Brouwer, D.L.

LAMO DE EsPINOSA, E. (1990). La sociedad reflexiva. Sujeto y objeto del conocimiento sociológico. Madrid: Centro de Investigaciones Sociológicas.

LASCH, (1980). The Culture of Narcissism. Londres: Abacus.

LÉvi-STrauss, C. (1979). «Introducción a la obra de Marcel Mauss». En Mauss, M. Sociología y antropología. Madrid: Tecnos.

- (1984). El pensamiento salvaje. México: FCE. 
- (1986). El totemismo en la actualidad. México: FCE.

- (1990). Mito y significado. Madrid: Alianza.

- (1995). Antropología estructural. Barcelona: Paidós.

- (1995). «Existen las organizaciones dualistas?». En Antropología estructural, p. 165-191.

LeVY-BRuHL, L. (1978). La mitología primitiva. Barcelona: Península.

LOWIE, R.H. (1983). Religiones primitivas. Madrid: Alianza.

LuHmann, N. (1990). Funktion der Religion. Suhrkamp: Frankfurt am Main.

- (1993). Teoría de la sociedad. México: Universidad de Guadalajara.

- (1998). Sistemas sociales. Barcelona: Anthropos.

MARETT, R.R. (1979). Threshold of Religion. Londres: Methuen \& Co. LTD.

MAuss, M. (1979). Sociología y antropología. Madrid: Tecnos.

McLennan, J.F. (1998). Primitive Marriage. Londres: Routledge/Thoemmes Press. OfFE, C. (1988). Partidos politicos y nuevos movimientos sociales. Madrid: Sistema. OrTIZ-OsÉs, A. (1986). La nueva filosofía hermenéutica. Hacia una razón axiológica posmoderna. Barcelona: Anthropos.

- (1993). Las claves simbólicas de nuestra cultura. Barcelona.

OтTO, R. (1991). Lo Santo. Madrid: Alianza.

PIAGET, J. (1977). El criterio moral del niño. Barcelona: Fontanella.

RAWLS, J. (1979). Una teoría de la justicia. México: FCE.

- (1993). Political Liberalism. Nueva York: Columbia University Press.

RIES, J. (ed.) (1994). Los ritos de iniciación. Bilbao: EGA.

SÁNCHEZ, C. (1999). Imaginación y sociedad. Madrid: Tecnos.

Simmel, G. (1977). La filosofía del dinero. Madrid: Instituto de Estudios Políticos.

SMith, R.W. (1927). Lectures on the Religion of Semites: The Fundamental Institutions.

Nueva York: Macmillan.

SOMBART, W. (1972). El burgués. Madrid: Alianza.

Tambiah, S.J. (1985). Culture, Thought and Social Action. Cambridge, Mass.: Harvard University Press.

WeBER, M. (1987). Ensayos sobre sociología de la religión. 3 vols. Madrid: Taurus.

- (1993). Economía y sociedad. Madrid: FCE. 